\title{
THE
}

\section{Chemical characteristics of continental outflow over the tropical South Atlantic Ocean from Brazil and Africa}

R. W. Talbot

J. D. Bradshaw

S. T. Sandholm

S. Smyth

D. R. Blake

See next page for additional authors

Follow this and additional works at: https://digitalcommons.uri.edu/gsofacpubs

Terms of Use

All rights reserved under copyright.

\section{Citation/Publisher Attribution}

Talbot, R. W., et al. (1996), Chemical characteristics of continental outflow over the tropical South Atlantic Ocean from Brazil and Africa, J. Geophys. Res., 101(D19), 24187-24202, doi: 10.1029/95JD03630.

Available at: https://doi.org/10.1029/95JD03630

This Article is brought to you for free and open access by the Graduate School of Oceanography at DigitalCommons@URI. It has been accepted for inclusion in Graduate School of Oceanography Faculty Publications by an authorized administrator of DigitalCommons@URI. For more information, please contact digitalcommons-group@uri.edu. 


\section{Authors}

R. W. Talbot, J. D. Bradshaw, S. T. Sandholm, S. Smyth, D. R. Blake, N. R. Blake, G. W. Sachse, J. E. Collins, Brian G. Heikes, B. E. Anderson, G. L. Gregory, H. B. Singh, B. L. Lefer, and A. S. Bachmeier 


\title{
Chemical characteristics of continental outflow over the tropical South Atlantic Ocean from Brazil and Africa
}

\author{
R. W. Talbot, ${ }^{1}$ J. D. Bradshaw, ${ }^{2}$ S. T. Sandholm, ${ }^{2}$ S. Smyth, ${ }^{2}$ D. R. Blake, ${ }^{3}$ N. R. \\ Blake, ${ }^{3}$ G. W. Sachse, ${ }^{4}$ J. E. Collins, ${ }^{5}$ B. G. Heikes, ${ }^{6}$ B. E. Anderson, ${ }^{4}$ G. L. \\ Gregory, ${ }^{4}$ H. B. Singh, ${ }^{7}$ B. L. Lefer, ${ }^{1}$ and A. S. Bachmeier ${ }^{5}$
}

\begin{abstract}
The chemical characteristics of air parcels over the tropical South Atlantic during September - October 1992 are summarized by analysis of aged marine and continental outflow classifications. Positive correlations between $\mathrm{CO}$ and $\mathrm{CH}_{3} \mathrm{Cl}$ and minimal enhancements of $\mathrm{C}_{2} \mathrm{Cl}_{4}$ and various chlorofluorocarbon (CFC) species in air parcels recently advected over the South Atlantic basin strongly suggest an impact on tropospheric chemistry from biomass burning on adjacent continental areas of Brazil and Africa. Comparison of the composition of aged Pacific air with aged marine air over the South Atlantic basin from 0.3 to $12.5 \mathrm{~km}$ altitude indicates potential accumulation of long-lived species during the local dry season. This may amount to enhancements of up to two-fold for $\mathrm{C}_{2} \mathrm{H}_{6}, 30 \%$ for $\mathrm{CO}$, and $10 \%$ for $\mathrm{CH}_{3} \mathrm{Cl}$. Nitric oxide and $\mathrm{NO}_{\mathrm{x}}$ were significantly enhanced (up to $\sim 1$ part per billion by volume (ppbv)) above $10 \mathrm{~km}$ altitude and poorly correlated with $\mathrm{CO}$ and $\mathrm{CH}_{3} \mathrm{Cl}$. In addition, median mixing ratios of $\mathrm{NO}$ and $\mathrm{NO}_{\mathrm{x}}$ were essentially identical in aged marine and continental outflow air masses. It appears that in addition to biomass burning, lightning or recycled reactive nitrogen may be an important source of $\mathrm{NO}_{\mathrm{x}}$ to the upper troposphere. Methane exhibited a monotonic increase with altitude from $\sim 1690$ to $1720 \mathrm{ppbv}$ in both aged marine and continental outflow air masses. The largest mixing ratios in the upper troposphere were often anticorrelated with $\mathrm{CO}, \mathrm{CH}_{3} \mathrm{Cl}$, and $\mathrm{CO}_{2}$, suggesting $\mathrm{CH}_{4}$ contributions from natural sources. We also argue, based on $\mathrm{CH}_{4} / \mathrm{CO}$ ratios and relationships with various hydrocarbon and CFC species, that inputs from biomass burning and the northern hemisphere are unlikely to be the dominant sources of $\mathrm{CO}, \mathrm{CH}_{4}$, and $\mathrm{C}_{2} \mathrm{H}_{6}$ in aged marine air. Emissions from urban areas would seem to be necessary to account for the distribution of at least $\mathrm{CH}_{4}$ and $\mathrm{C}_{2} \mathrm{H}_{6}$. Over the African and South American continents an efficient mechanism of convective vertical transport coupled with large-scale circulations conveys biomass burning, urban, and natural emissions to the upper troposphere over the South Atlantic basin. Slow subsidence over the eastern South Atlantic basin may play an important role in establishing and maintaining the rather uniform vertical distribution of long-lived species over this region. The common occurrence of values greater than 1 for the ratio $\mathrm{CH}_{3} \mathrm{OOH} / \mathrm{H}_{2} \mathrm{O}_{2}$ in the upper troposphere suggests that precipitation scavenging effectively removed highly water soluble gases $\left(\mathrm{H}_{2} \mathrm{O}_{2}, \mathrm{HNO}_{3}, \mathrm{HCOOH}\right.$, and $\mathrm{CH}_{3} \mathrm{COOH}$ ) and aerosols during vertical convective transport over the continents. However, horizontal injection of biomass burning products over the South Atlantic, particularly water soluble species and aerosol particles, was frequent below $6 \mathrm{~km}$ altitude.
\end{abstract}

\footnotetext{
${ }^{1}$ Institute for the Study of Earth, Oceans and Space, University of New Hampshire, Durham.

'School of Earth and Atmospheric Sciences, Georgia Institute of Technology, Atlanta.

${ }^{3}$ Department of Chemistry, University of California, Irvıne.

${ }^{4}$ NASA Langley Research Center, Hampton, Virginia

${ }^{5}$ Lockheed Engineering and Sciences Company, Hampton, Virginia.

${ }^{6}$ Center for Atmospheric Chemistry Studies, University of Rhode Island, Narragansett.

${ }^{7}$ NASA Ames Research Center, Moffett Field, Califomia

Copyright 1996 by the American Geophysican Union.

Paper number 95JDO3630.

0148-0227/96/95JD-03630\$09.00
}

\section{Introduction}

Field measurements of biomass fire emissions in the tropics have been sparsely scattered over tropical forest and savanna regions of Brazil and the continent of Africa during the last decade. The scope of these studies has been limited geographically and also chemically to a small suite of species at each location. These studies show greatly enhanced local mixing ratios of tropospheric $\mathrm{CO}, \mathrm{CO}_{2}, \mathrm{CH}_{4}, \mathrm{HCOOH}, \mathrm{CH}_{3} \mathrm{COOH}, \mathrm{NO}$, selected nonmethane hydrocarbons, particulate elemental species such as $\mathrm{P}, \mathrm{S}, \mathrm{Cl}, \mathrm{Mg}, \mathrm{K}, \mathrm{Ca}$, graphitic (soot) $\mathrm{C}$, and organic carbon [Leslie, 1981; Greenberg et al., 1984; Cachier et al., 
1985, 1989; Andreae et al., 1988; Kirchhoff et al., 1990, 1994; Helas et al., 1992; Rudolph et al., 1992]. Estimates suggest that these emissions are important on various scales, ranging from causing regional air pollution problems [Kirchhoff et al., 1990] to being a significant global source of tropospheric species [Crutzen et al., 1979; Andreae et al., 1988; Crutzen and Andreae, 1990].

The environmental consequences of biomass fires are diverse. Denitrification during biomass burning, where as much as $50 \%$ of the fuel nitrogen is released as $\mathrm{N}_{2}$ [Kuhlbusch et al., 1991], may cause sizable loss of fixed nitrogen from tropical ecosystems [Crutzen and Andreae, 1990]. Burning emissions of some C, N, and $\mathrm{S}$ compounds leads to production of acidic gases, and these subsequently cause acid rainfall [Lacaux et al., 1992]. Release of smoke particles from biomass fires may provide copius amounts of cloud condensation nuclei, and therefore play a role in cloud formation and precipitation in the tropics [Crutzen and Andreae, 1990; Cachier and Ducret, 1991].

Perhaps one of the most important consequences of biomass fire emissions is widespread photochemical production of $\mathrm{O}_{3}$ coupled with its coincident rapid transport. This phenomenon has been observed in the tropics on regional [Andreae et al., 1992; Kirchhoff et al., 1990, 1994] to hemispheric scales [Fishman et al., 1991]. In addition, the seasonality and large-scale influence of biomass fire emissions in the southern hemisphere appears to be evident in the annual cycles of $\mathrm{CO}$ and $\mathrm{CH}_{4}$ [Fishman et al., 1991].

Together these observations suggest that a large-scale, comprehensive investigation of biomass fire emissions should be conducted in the southern hemisphere concentrating on the influence of fires occurring in Brazil and southern Africa during the local dry season. The NASA TRACE A (Transport and Chemistry Near the Equator - Atlantic) airborne expedition in September - October 1992 provided a unique database to address many of the important issues related to these particular fire emissions. This paper summarizes the chemical characteristics of air parcels exported from the South American and African continents out over the South Atlantic and Indian Oceans during the local dry season. We argue that the polluted composition of these air parcels was largely biased by biomass fire emissions on both continents and that this source is a major cause of hemispheric scale air pollution. The impact of these emissions on tropospheric chemical cycles in the southern hemisphere is the focus of companion papers [Heikes et al., this issue; Jacob et al., this issue; Kirchhoff et al., this issue; Olson et al., this issue].

\section{Experiment}

The TRACE A expedition was conducted aboard the NASA Ames DC-8 research aircraft. Transit and intensive site science missions composed 19 flights, each averaging 8 hours in duration and covering the altitude range of $0.3-12.5 \mathrm{~km}$. In this paper we utilize data obtained over the South Atlantic and Indian Oceans, centered in the geographic grid bounded by $5^{\circ} \mathrm{N}-35^{\circ} \mathrm{S}$ latitude and $41^{\circ} \mathrm{E}$ to $55^{\circ} \mathrm{W}$ longitude. A map of this region with the flight tracks over the tropical South Atlantic superimposed on it is shown in Figure 1. The aircraft base of operations for these missions progressed from (1) Recife (one mission) to Brasilia (three missions), and then to Rio de Janerio (one mission) in Brazil; (2) Johannesburg (three missions) in South Africa; (3)

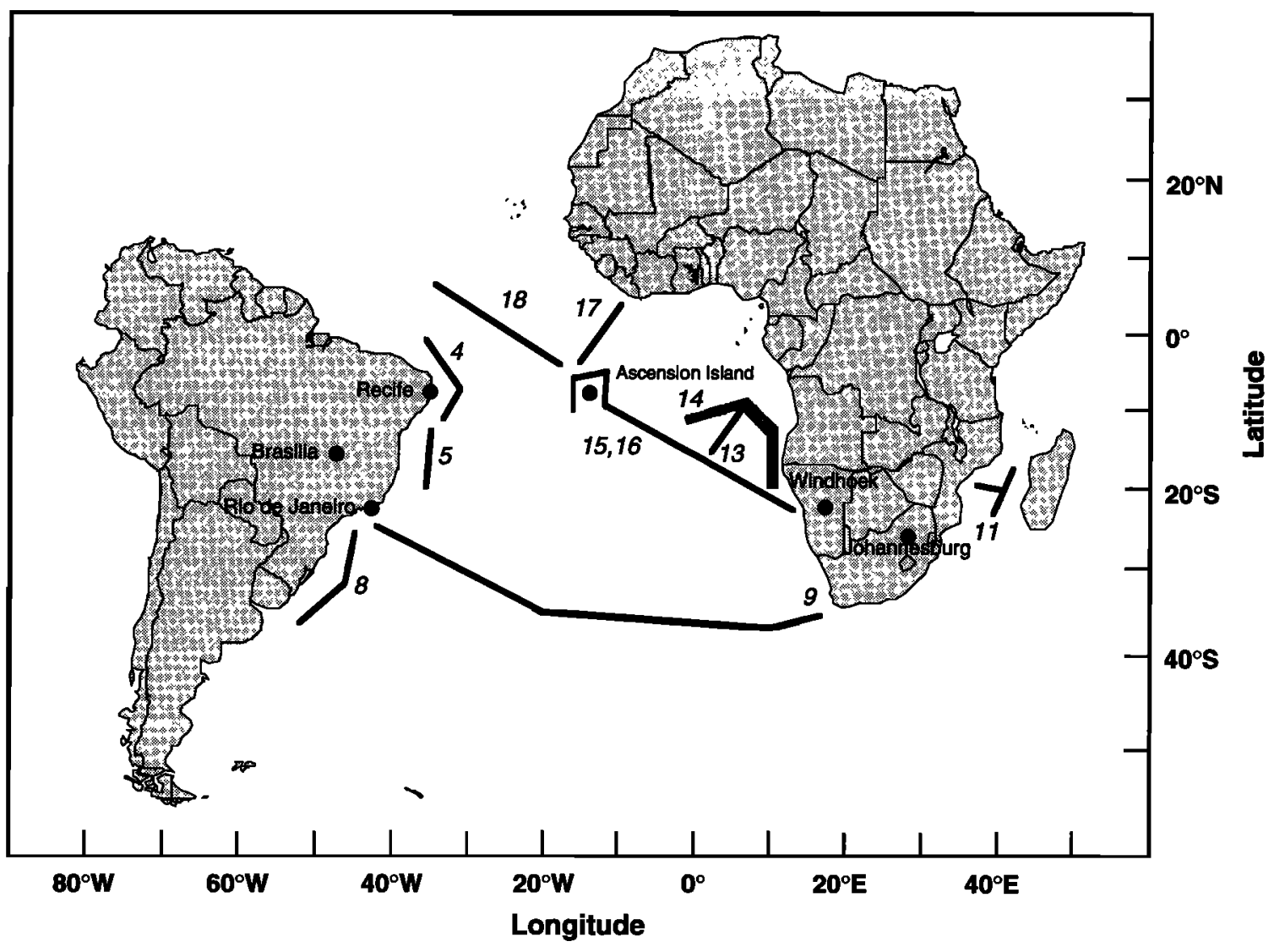

Figure 1. Map of the (TRACE A) study area with the DC-8 flight paths over the tropical South Atlantic Ocean superimposed. Solid lines depict aircraft flight tracks and associated numbers indicate the particular mission. Bases of DC-8 operation are also shown. 
Windhoek (four missions) in Namibia; and finally (4) Ascension Island (two missions) in the central tropical South Atlantic.

The overall scientific rationale and description of the individual aircraft missions is described in the TRACE A overview paper [Fishman et al., this issue]. The salient features of the largescale meteorological regime are provided by Bachmeier and Fuelberg [this issue]. Since we present a broad description of the observed chemical composition of air parcels in continental outflow conditions, it is impractical to provide the details here for the individual species measurements. Instead, the philosophy adopted for TRACE A was to present measurement-specific details in the mission overview paper [Fishman et al., this issue]. To summarize the chemistry of continental outflow, 29 individual gas phase species were selected plus aerosol number density information binned in the $0.12^{-}$to $3.1-\mu \mathrm{m}$-diameter range. The chemical composition of the atmospheric aerosol was not determined during TRACE $A$. Due to questions regarding the exact suite of compounds being measured by current total reactive nitrogen $\left(\mathrm{NO}_{\mathrm{y}}\right)$ instruments [S.T. Sandholm, et al., Comparison of $\mathrm{N}_{\mathrm{x}} \mathrm{O}_{\mathrm{y}}$ budgets from NASA's ABLE-3, PEM-W, and TRACE-A measurement programs: An update, J. Geophys. Res., submitted, 1996], we use the sum of the species-specific measurements to represent $\mathrm{NO}_{\mathrm{y}}\left(\Sigma \mathrm{NO}_{\mathrm{y} 1}=\right.$ nitric oxide $[\mathrm{NO}]+$ nitrogen dioxide $\left[\mathrm{NO}_{2}\right]+$ nitric acid $\left[\mathrm{HNO}_{3}\right]+$ peroxyacetylnitrate [PAN].

\section{Formulation of Continental Outflow Data Set}

\subsection{Meteorological Basis}

The detailed synoptic meteorological scheme leading to outflow of South American and African continental air masses over the South Atlantic and Indian Oceans is described elsewhere [Pickering et al., 1994; Garstang et al, this issue; Bachmeier and Fuelberg, this issue]. This section provides a brief description of the large-scale flow regime which established the general environmental conditions for outflow of continental air parcels to the marine atmosphere.

Prior to the TRACE A mission, relatively few details were known about the atmospheric flow patterns over the tropical South Atlantic Ocean. This region is under the general influence of slow subsidence, as evidenced by the clear skies and sparce precipitation. A major oceanic anticyclone is located near $30^{\circ} \mathrm{S}$ which tends to dominate the flow in the TRACE A study area. This feature is sufficiently large that it can sweep air from over Brazil or Africa to the central tropical South Atlantic in 2 - 3 days [Krishnamurti et al., 1993]. Weaker cyclonic and anticyclonic circulations are located over Africa that transport air parcels either to the east over the Indian Ocean or westward to the tropical South Atlantic Ocean. Anticyclonic flow over southcentral Brazil is confined by the origraphic feature of the Andes Mountains on the west, so most of the air exits the continent to the southeast. The NASA DC-8 aircraft sampled each of these persistent continental outflow regimes during the TRACE A expedition.

\subsection{Measurement Database}

Extensive processing of final archived data was required to obtain the data products utilized in our analysis here. Because of the diversity in measurement time resolutions for the species of interest, merged data products were used on various timescales. The principal database was 90 -s averaged data that corresponded to the highest resolution $\mathrm{NO}_{\mathrm{x}}\left(\mathrm{NO}+\mathrm{NO}_{2}\right.$ ) measurements. The measurements of faster response instruments (e.g., meteorological parameters, aerosol number density, and species including $\mathrm{O}_{3}$, $\mathrm{CO}, \mathrm{CO}_{2}, \mathrm{CH}_{4}$, and $\mathrm{N}_{2} \mathrm{O}$ ) were averaged to coincide with the 90 -s time base. Merged data products on various time resolutions were used for species with time resolutions longer than 90 s (i.e., acidic gases, peroxides, peroxyacetylnitrate, hydrocarbons, and halocarbons).

\subsection{Classification of the Database}

Isentropic back trajectories were used to identify time intervals on constant altitude flight legs where the sampled air parcels had recently ( $<1-5$ days) passed over continental areas of Brazil or southern Africa [Bachmeier and Fuelberg, this issue]. The chemical characteristics of continental outflow are captured in this air mass classification. A second major data group was compiled which contained air parcels from over the ocean that had not passed over continental areas within the past 5 days. These data represent the aged marine air classification. For both air mass classifications, data were included for altitude changes of $3 \mathrm{~km}$ or less where the chemistry (as indicated mainly by NO, $\mathrm{CO}$, and $\mathrm{C}_{2} \mathrm{H}_{6}$ ) was uniform. Data obtained during spirals was not used here due to heterogeneity in air masses and practical limitations imposed by the vertical density of trajectories. Air parcels of primarily stratospheric composition were also eliminated from the data groups using $\mathrm{N}_{2} \mathrm{O}$, which has a uniform tropospheric mixing ratio of $308-312$ parts per billion by volume (ppbv). A cutoff mixing ratio of $308 \mathrm{ppbv}$ and above was used to distinguish tropospheric from stratospheric $(<308$ ppbv) air.

Two outflow data sets were developed, one for air parcels sampled over the western South Atlantic and the other for the eastern basin near Africa. This latter set included data obtained over the Indian Ocean during one flight between Africa and Madagascar. For some analyses here, the outflow and aged marine data sets were divided into three altitude bands: $0-4.9$ $\mathrm{km}, 5-9.9 \mathrm{~km}$, and $10-13 \mathrm{~km}$. These altitude breakdowns provided chemical depictions of air masses in the lower, middle, and upper troposphere. The rationale for these divisions was based on the fact that above $10 \mathrm{~km}$ altitude the air parcels had distinctly different chemistry than below this level; thus these data comprised one group and the region below $10 \mathrm{~km}$ was split evenly into two more groups. For most species this provided an approximately equal distribution of data between the two loweraltitude bins.

\section{Characteristics of Air Parcels Over the Tropical South Atlantic}

\subsection{Aged Marine Air Parcels}

The aged marine classification represents air parcels that have not been recently ( $<5$ days) influenced by continental emissions. The chemistry of this classification is summarized in Table 1. The most aged air parcels appear to be contained below $5 \mathrm{~km}$ altitude, as evidenced by the smallest mixing ratios there of $\mathrm{NO}$, $\mathrm{C}_{2} \mathrm{H}_{6}, \mathrm{C}_{3} \mathrm{H}_{8}, \mathrm{C}_{2} \mathrm{H}_{2}$, and lowest ratio values of $\mathrm{C}_{2} \mathrm{H}_{2} / \mathrm{CO}$ and $\mathrm{C}_{3} \mathrm{H}_{8} /$ $\mathrm{C}_{2} \mathrm{H}_{6}$. In the marine boundary layer the sampled air parcels had trajectories leading typically back to high latitudes over the South Atlantic. These air parcels probably had been over the ocean for a week or two, based on mixing ratios in the $65 \mathrm{ppbv}$ range for $\mathrm{CO}$ and 300-400 pptv for $\mathrm{C}_{2} \mathrm{H}_{6}$. Deposition to the surface ocean would also deplete many species. A detailed discussion of the processes affecting the chemistry of the marine boundary layer is in a companion paper [Heikes et al., this issue].

Within the aged marine air classification, several species showed a trend of increased mixing ratio with altitude (Figure 2). The most dramatic increase was above $10 \mathrm{~km}$. Air parcels in the 10 to $13-\mathrm{km}$ range appear to show a combustion influence based on the increased mixing ratios of $\mathrm{C}_{2} \mathrm{H}_{6}, \mathrm{C}_{3} \mathrm{H}_{8}$, and $\mathrm{C}_{2} \mathrm{H}_{2}$ compared to those at lower altitudes. Halocarbon industrial tracers did not follow the trend exhibited by these hydrocarbon species, but $\mathrm{CH}_{3} \mathrm{Cl}$ did. The $\mathrm{CH}_{3} \mathrm{Cl}$ enhancement is evidence for a biomass 
Table 1. Mixing Ratios of Principal Species Measured in Aged Marine Air Over the Tropical South Atlantic Ocean

\begin{tabular}{|c|c|c|c|c|c|c|c|c|c|c|c|c|c|c|c|}
\hline \multirow[b]{2}{*}{ Species } & \multicolumn{5}{|c|}{$0-4.9 \mathrm{~km}$} & \multicolumn{5}{|c|}{$5-99 \mathrm{~km}$} & \multicolumn{5}{|c|}{$10-13 \mathrm{~km}$} \\
\hline & Mean & s.d. & Median & Range & $\mathrm{N}$ & Mean & s.d. & Median & Range & $\mathrm{N}$ & Mean & s.d. & Median & Range & $\mathrm{N}$ \\
\hline NO & 13 & 9.5 & 10 & $1.9-89$ & 203 & 49 & 51 & 30 & $1.6-353$ & 366 & 174 & 127 & 114 & $7.6-805$ & 549 \\
\hline $\mathrm{NO}_{\mathrm{x}}$ & 43 & 22 & 38 & $14-129$ & 158 & 68 & 56 & 57 & $17-533$ & 215 & 182 & 133 & 121 & $1.2-908$ & 549 \\
\hline $\mathrm{HNO}_{3}$ & 191 & 131 & 61 & $8.0-566$ & 159 & 85 & 66 & 63 & $14-383$ & 173 & 65 & 33 & 45 & $14-180$ & 254 \\
\hline PAN & 62 & 86 & 25 & $1.0-461$ & 87 & 181 & 92 & 179 & $27-559$ & & 198 & 72 & 186 & $76-429$ & 175 \\
\hline $\mathbf{N N O}_{n}$ & 219 & 158 & 187 & $98-170$ & 183 & 195 & 128 & 164 & $103-658$ & 280 & 256 & 167 & 201 & $102-1163$ & 487 \\
\hline $\mathrm{O}_{3}$ & 42 & 14 & 39 & $21-80$ & 373 & 58 & 14 & 57 & $32-101$ & 468 & 71 & 13 & 70 & $40-102$ & 685 \\
\hline $\mathrm{CO}$ & 76 & 12 & 72 & $60-100$ & 368 & 82 & 11 & 83 & $59-104$ & 452 & 86 & 8 & 87 & $63-102$ & 677 \\
\hline $\mathrm{CH}_{4}$ & 1687 & 11 & 1683 & $1663-1720$ & 369 & 1704 & 13 & 1703 & $1673-1736$ & 432 & 1716 & 10 & 1717 & $1684-1742$ & 677 \\
\hline $\mathrm{CO}_{3}$ & 355.0 & 0.78 & 354.9 & $3525-357.5$ & 349 & 354.6 & 0.77 & 574.7 & $351.9-356.5$ & 443 & 354.0 & 1.1 & 353.9 & $349.9-356.9$ & 626 \\
\hline $\mathrm{N}_{2} \mathrm{O}$ & 309.6 & 0.43 & 309.0 & $308.7-3111$ & 191 & 309.9 & 0.48 & 309.5 & $308.4-311.1$ & 295 & 310.0 & 0.47 & 309.9 & $308.0-311.0$ & 532 \\
\hline $\mathrm{C}_{2} \mathrm{H}_{2} / \mathrm{CO}$ & 0.18 & 0.07 & 011 & $0.11-0.40$ & 191 & 022 & 009 & 0.15 & $0.11-0.53$ & 191 & 0.26 & 006 & 0.18 & $0.12-0.45$ & 225 \\
\hline $\mathrm{C}_{3} \mathrm{H}_{8} / \mathrm{C}_{2} \mathrm{H}_{6}$ & 0.06 & 0.08 & 0.03 & $0.02-056$ & 213 & 0.08 & 0.05 & 0.05 & $002-0.26$ & 203 & 0.50 & 0.33 & 025 & $011-0.96$ & 242 \\
\hline $\mathrm{C}_{2} \mathrm{H}_{6}$ & 397 & 102 & 313 & $286-854$ & 214 & 537 & 195 & 425 & $287-1448$ & 203 & 642 & 188 & 590 & $383-1773$ & 248 \\
\hline $\mathrm{C}_{3} \mathrm{H}_{4}$ & 24 & 32 & 15 & $71-339$ & 214 & 51 & 53 & 35 & $7.1-369$ & 202 & 73 & 55 & 60 & $19-484$ & 246 \\
\hline $\mathrm{C}_{2} \mathrm{H}_{2}$ & 60 & 27 & 38 & $27-164$ & 213 & 80 & 37 & 60 & $33-324$ & 203 & 88 & 23 & 72 & $42-159$ & 248 \\
\hline $\mathrm{C}_{2} \mathrm{H}_{4}$ & 13 & 15 & 16 & $2-184$ & 168 & 9 & 8 & 4 & $2 \cdot 69$ & 139 & 9 & 3 & 7 & $3-22$ & 186 \\
\hline $\mathrm{CH}_{3} \mathrm{Cl}$ & 616 & 23 & 613 & $549-668$ & 215 & 634 & 30 & 629 & $579-812$ & 203 & 652 & 40 & 644 & $618-857$ & 248 \\
\hline $\mathrm{C}_{2} \mathrm{Cl}_{4}$ & 3.5 & 1.9 & 2.6 & $2.3-27$ & 200 & 30 & 0.95 & 2.9 & $0.3-8.5$ & 171 & 3.0 & 0.71 & 2.9 & $0.9-5.1$ & 219 \\
\hline CFC-11 & 259.5 & 3.4 & 259.9 & $248.5-265.8$ & 202 & 260.1 & 4.2 & 260.0 & $245.7-268.5$ & 174 & 260.7 & 2.7 & 260.5 & $250.7-268.9$ & 221 \\
\hline CFC-12 & 489.0 & 4.4 & 488.3 & $479.4-507.6$ & 210 & 491.0 & 4.4 & 490.7 & $483.2-504.2$ & 172 & 494.7 & 3.3 & 494.5 & $488.4-506.1$ & 219 \\
\hline CFC-113 & 78.8 & 12 & 78.8 & $75.6-81.1$ & 202 & 78.3 & 1.6 & 78.0 & $75.3-86.6$ & 175 & 79.0 & 1.7 & 79.0 & $72.7-87.9$ & 221 \\
\hline $\mathrm{CH}_{3} \mathrm{CCl}_{3}$ & 124 & 6.7 & 124 & $102-134$ & 210 & 122 & 5.2 & 122 & $98-137$ & 173 & 123 & 58 & 122 & $106-135$ & 215 \\
\hline $\mathrm{CCl}_{4}$ & 101 & 2.4 & 101 & $85-106$ & 215 & 98 & 4.6 & 98 & $72-110$ & 203 & 97 & 6 & 96 & $71-106$ & 246 \\
\hline $\mathrm{C}_{6} \mathrm{H}_{6}$ & 14 & 10 & 12 & $3.1-110$ & 212 & 13 & 8.7 & 12 & $25-61$ & 175 & 13 & 6.7 & 12 & $2.8-37$ & 221 \\
\hline $\mathrm{HCOOH}$ & 516 & 313 & 415 & $10-1554$ & 146 & 693 & 415 & 595 & $175-1876$ & 169 & 576 & 282 & 550 & $93-1589$ & 253 \\
\hline $\mathrm{CH}_{3} \mathrm{COOH}$ & 1023 & 612 & 850 & $13-2550$ & 113 & 1355 & 595 & 975 & $426-4112$ & 119 & 1363 & 682 & 1095 & $490-2977$ & 139 \\
\hline $\mathrm{H}_{2} \mathrm{O}_{2}$ & 1784 & 1160 & 915 & $103-6051$ & 228 & 549 & 443 & 475 & $84-3552$ & 265 & 131 & 93 & 75 & $34-543$ & 294 \\
\hline $\mathrm{CH}_{3} \mathrm{OOH}$ & 623 & 268 & 308 & $37-1439$ & 219 & 161 & 115 & 125 & $15-840$ & 236 & 46 & 48 & 25 & $7.5-376$ & 162 \\
\hline $\mathrm{CH}_{2} \mathrm{O}$ & 116 & 55 & 65 & $52-247$ & 31 & 58 & 17 & 55 & $36-95$ & 12 & 85 & 56 & 65 & $39-284$ & 67 \\
\hline Aerosols & 143 & 201 & 54 & $7.3-1680$ & 338 & 51 & 64 & 26 & $1.7-616$ & 443 & 23 & 16 & 16 & $3.4-65$ & 627 \\
\hline
\end{tabular}

Mixing ratios are stated in parts per trillion by volume (pptv); except for $\mathrm{CO}, \mathrm{CH}_{4}, \mathrm{~N}_{2} \mathrm{O}$ and $\mathrm{O}_{3}$ that are in parts per billion by volume (ppbv), and $\mathrm{CO}$ in parts per million by volume (ppmv); s.d. states the 1 standard deviation. $\mathrm{C}_{2} \mathrm{H}_{2} / \mathrm{CO}$ ratio is stated in pptv/ppbv; and aerosols are stated in number per cubic centimeter for $0.12-$ to $31-\mu \mathrm{m}$ diameter range.

burning influence on the chemistry of aged air at altitudes above the marine boundary layer [Crutzen et al., 1979; Crutzen and Andreae, 1990].

Further evidence for a combustion signal in the aged marine air parcels comes from comparison of these data to those obtained during mission 8 (see Figure 1) where trajectories indicated air of Pacific origin was sampled south of Brazil. The air parcels sampled on mission 8 had very uniform chemistry, with mean mixing ratios of $\mathrm{NO}_{\mathrm{x}}$ of $18 \mathrm{pptv}, 325 \mathrm{pptv}$ of $\mathrm{C}_{2} \mathrm{H}_{6}, 45$ pptv of $\mathrm{C}_{2} \mathrm{H}_{2}, 600 \mathrm{pptv}$ of $\mathrm{CH}_{3} \mathrm{Cl}$, and 65 ppbv of $\mathrm{CO}$. The composition and backward trajectories for these air parcels indicated that they had probably been over the Pacific Ocean without contacting emissions from continental areas for at least 10 days [Gregory et al., 1996].

Comparison of mission 8 data with values for aged marine air suggests the possibility that emissions from biomass burning may have elevated the mixing ratios of many species in the general background air (called aged marine here) over the tropical South Atlantic. This may reflect gradual accumulation of longer-lived species during the local dry season, since our measurements occurred at the latter stage of it. Convective transport of polluted air from low to high altitude over the continents most likely explains the high-altitude enhancements of some species [Kleinman and Daum, 1991; Pickering et al., 1992, this issue]. Colder temperatures and low $\mathrm{OH}$ concentration would increase species lifetimes once they were in this region [Jacob et al., this issue].

The elevated mixing ratios of $\mathrm{NO}$ and $\mathrm{NO}_{\mathrm{x}}$ in the 10 -to $13-\mathrm{km}$ altitude range stand out from the rest of the chemistry of these aged air parcels. There does not appear to be strong evidence for recent ( $<5$ days) combustion inputs to these air parcels. Indeed, median mixing ratios of most species are indicative of moderately aged air [Singh and Zimmerman, 1992]. Poor correlations $\left(r^{2}<\right.$ 0.3 ) between $\mathrm{NO}$ (or $\mathrm{NO}_{x}$ ) and $\mathrm{CO}$ or $\mathrm{CH}_{3} \mathrm{Cl}$ suggest a different source for the NO other than biomass burning. In addition, data presented in the next section of this paper shows that NO and $\mathrm{NO}_{\mathbf{x}}$ mixing ratios in the upper troposphere were not significantly different in aged marine and continental influenced air masses. 


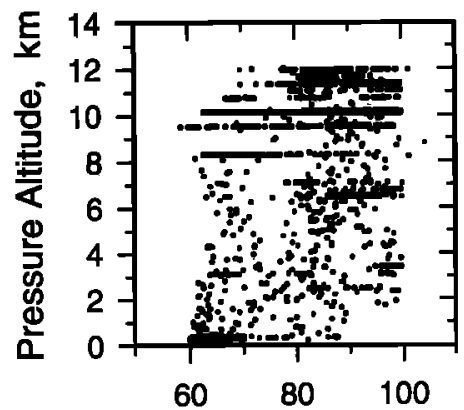

$\mathrm{CO}, \mathrm{ppbv}$

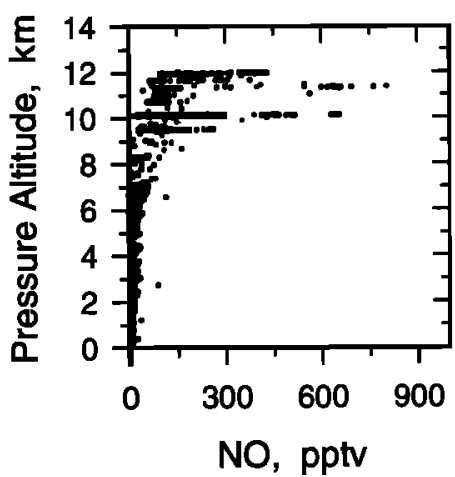

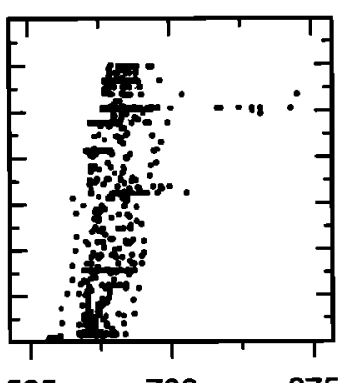
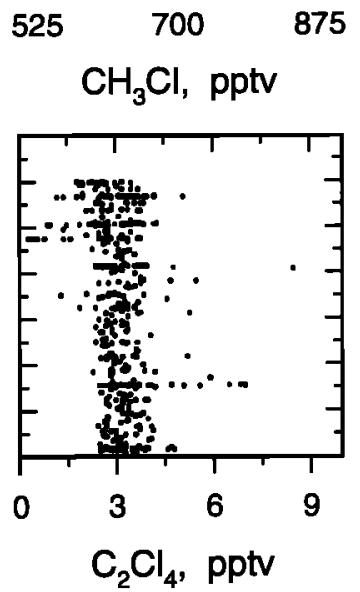
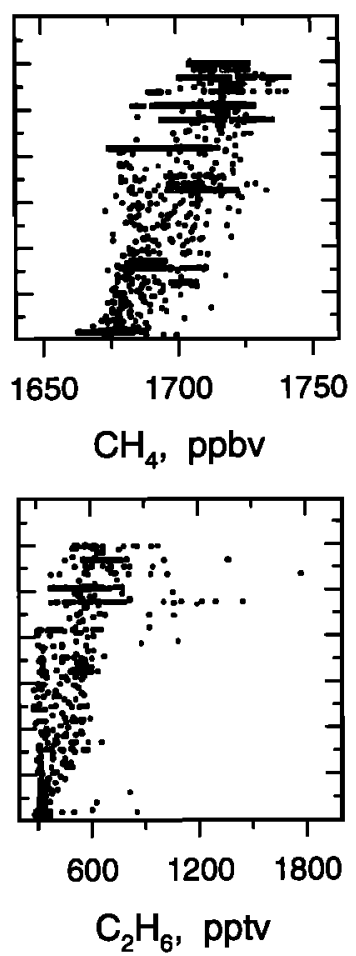
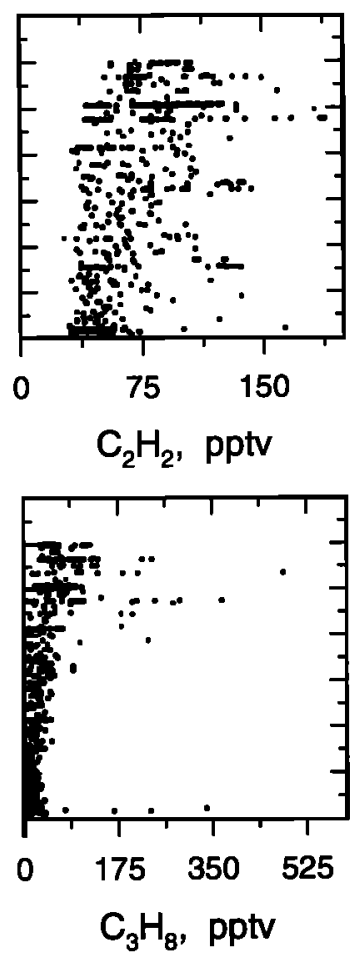

Figure 2. Vertical distribution of selected species in aged marine air over the tropical South Atlantic Ocean.

This is further evidence for important sources of $\mathrm{NO}_{\mathrm{x}}$ besides biomass burning. Note that while NO mixing ratios approached 1 ppbv, CO remained at less than 100 ppbv (Figure 2). Two potential sources of NO that would not provide significant amounts of other tropospheric species (e.g., $\mathrm{CO}$ ) are jet aircraft emissions and lightning. In the TRACE A study area it is likely that lightning is an important source of NO in the middle-toupper troposphere [Smyth et al., this issue].

\subsection{Continental Outflow Air Parcels}

The chemical characteristics of the continental outflow air parcels over the western and eastern basins of the tropical South Atlantic are summarized in Tables 2 and 3, respectively. The vertical distribution of selected species is shown in Figures 3 and 4. The composition of the outflow air parcels on both sides of the South Atlantic was similar, but there were some subtle differences. At low altitude over the western basin the industrial tracer $\mathrm{C}_{2} \mathrm{Cl}_{4}$ showed significant isolated enhancement (up to 87 pptv) relative to aged marine air $(\approx 3 \mathrm{pptv}$, Table 1$)$. Note that corresponding enhancements in chlorofluorocarbon species (CFCs) were not observed. The air mass back trajectories indicated that these anthropogenic emissions probably originated from the urbanized east coast region of Brazil that extends from Recife south to the Rio de Janeiro/São Paulo area. It is likely that emissions from this urban region contributed to species enhancements observed in air parcels at $0-5 \mathrm{~km}$ altitude east of Brazil. In contrast, direct industrial emissions appear to have had minimal impact on the air parcels sampled over the eastern basin of the tropical South Atlantic, as industrial tracer compounds were not enhanced above their mixing ratio median value in aged marine air.

Hydrocarbon species are valuable tracers that can be used to study photochemical and atmospheric transport processes [McKeen and Liu, 1993]. The ratio of shorter- to longer-lived species is particularly useful in this respect. Here we use the ratios $\mathrm{C}_{2} \mathrm{H}_{2} / \mathrm{CO}$ and $\mathrm{C}_{3} \mathrm{H}_{8} / \mathrm{C}_{2} \mathrm{H}_{6}$ to facilitate comparisons of various air parcels. For an $[\mathrm{OH}]$ of $1 \times 10^{6}$ molecules $\mathrm{cm}^{-3}$, a reasonable value for the TRACE A study area [Jacob et al., this issue], $\mathrm{C}_{2} \mathrm{H}_{2}$ and $\mathrm{C}_{3} \mathrm{H}_{8}$ have atmospheric lifetimes near 2 weeks compared to about 2 months for $\mathrm{CO}$ and $\mathrm{C}_{2} \mathrm{H}_{6}$.

On the average, the value of the ratio $\mathrm{C}_{2} \mathrm{H}_{2} / \mathrm{CO}$ was greater over the western basin compared to the eastern basin. This suggests that outflow air parcels sampled over the western basin contained more recent emissions, especially below $5 \mathrm{~km}$ altitude. In Brazil, biomass burning was occurring in the savannas located several hundred kilometers inland, and the largest urban areas are located right along the coast. Emissions from both of these sources could easily be swept off the coast out over the western South Atlantic within a day or so.

The situation in southern Africa was not conducive to such direct outflow of polluted air parcels [Garstang et al., this issue]. Here the fires were centered in the middle or eastern portions of the continent (e.g., in Zambia). Emissions from this area would need a day or two just to reach the western coast of Africa which is located at an elevation of about $1100 \mathrm{~m}$. Furthermore, air parcels appear to become periodically entrained in circular flow patterns over southern Africa for days at a time [Garstang et al., this issue].

As the emissions are advected off the African coast over the eastern basin of the South Atlantic at an altitude greater than 1 $\mathrm{km}$, their transport into the marine boundary layer is usually hindered by a thick stratocumulus cloud deck. This persistent stratus deck extends over a significant amount of the basin's eastern area [Thompson et al., 1993]. The marine boundary layer typically contained quite aged marine air with elevated mixing ratios of some species (e.g., $\mathrm{HNO}_{3}$ ) that appeared to originate by downward infiltration from the polluted region above the stratus deck [Heikes et al., this issue].

The vertical distributions of the combustion products $\mathrm{CO}$, $\Sigma \mathrm{NO}_{\mathrm{y}}, \mathrm{C}_{2} \mathrm{H}_{6}$, and $\mathrm{CH}_{3} \mathrm{Cl}$ over the western South Atlantic were relatively constant above $2 \mathrm{~km}$ altitude (Figure 3 ). Mixing ratios of $\mathrm{CO}, \mathrm{\Sigma NO}_{\mathrm{y}}$, and $\mathrm{C}_{2} \mathrm{H}_{6}$ were elevated roughly two-fold over their median values in aged marine air, while $\mathrm{CH}_{3} \mathrm{Cl}$ was 
Table 2. Mixing Ratios of Principal Species Measured in Continental Outflow Over the Western South Atlantic Ocean

\begin{tabular}{|c|c|c|c|c|c|c|c|c|c|c|c|c|c|c|c|}
\hline \multirow[b]{2}{*}{ Species } & \multicolumn{5}{|c|}{$0-4.9 \mathrm{~km}$} & \multicolumn{5}{|c|}{$5-9.9 \mathrm{~km}$} & \multicolumn{5}{|c|}{$10-13 \mathrm{~km}$} \\
\hline & Mean & s.d. & Median & Range & $\mathrm{N}$ & Mean & s.d. & Median & Range & N & Mean & s.d. & Median & Range & $\mathrm{N}$ \\
\hline NO & 30 & 16 & 22 & $11-102$ & 41 & 160 & 129 & 91 & $15-559$ & 116 & 107 & 26 & 100 & $4.5-175$ & 121 \\
\hline $\mathrm{NO}_{\mathrm{x}}$ & 94 & 40 & 67 & $57-220$ & 39 & 109 & 47 & 103 & $40-218$ & 27 & 142 & 41 & 117 & $40-274$ & 121 \\
\hline $\mathrm{HNO}_{3}$ & 458 & 97 & 455 & $215-566$ & 23 & 47 & 13 & 46 & $32-96$ & 47 & 40 & 13 & 43 & $26-96$ & 67 \\
\hline PAN & 531 & 265 & 520 & $262-1151$ & 16 & 288 & 242 & 256 & $71-1538$ & 42 & 380 & 182 & 402 & $120-1119$ & 50 \\
\hline $\mathrm{ZNO}_{\mathrm{y} 1}$ & 779 & 395 & 761 & $148-1775$ & 27 & 366 & 237 & 306 & $116-1634$ & 80 & 316 & 206 & 203 & $100-1147$ & 115 \\
\hline $\mathrm{O}_{3}$ & 50 & 5 & 50 & $25-67$ & 61 & 64 & 11 & 64 & $47-88$ & 145 & 76 & 11 & 77 & $55-97$ & 169 \\
\hline $\mathrm{CO}$ & 147 & 18 & 146 & $89-184$ & 59 & 102 & 33 & 92 & $55-189$ & 145 & 110 & 31 & 98 & $70-173$ & 168 \\
\hline $\mathrm{CH}_{4}$ & 1702 & 6 & 1702 & $1688-1712$ & 59 & 1713 & 9.9 & 1712 & $1695-1736$ & 140 & 1721 & 8.2 & 1721 & $1701-1748$ & 168 \\
\hline $\mathrm{CO}_{3}$ & 357.7 & 0.75 & 3576 & $3555-3594$ & 56 & 355.5 & 13 & 3553 & $353.0-3590$ & 125 & 355.2 & 1.0 & 355.0 & $353.5-358.2$ & 163 \\
\hline $\mathrm{N}_{2} \mathrm{O}$ & 310.1 & 0.39 & 309.8 & $3088-310.9$ & 37 & 310.3 & 0.38 & 3102 & $309.2-310.9$ & 39 & 310.3 & 0.36 & 310.2 & $309.1-311.0$ & 119 \\
\hline $\mathrm{C}_{2} \mathrm{H}_{2} / \mathrm{CO}$ & 2.7 & 1.3 & 2.6 & $1.1-6.9$ & 47 & 16 & 0.72 & 1.5 & $0.66-3.4$ & 58 & 1.2 & 0.51 & 0.98 & $074-25$ & 28 \\
\hline $\mathrm{C}_{3} \mathrm{H}_{8} / \mathrm{C}_{2} \mathrm{H}_{6}$ & 0.13 & 0.16 & 0.09 & $0.08-1.1$ & 47 & 0.11 & 0.06 & 0.09 & $0.01-0.26$ & 60 & 0.12 & 003 & 010 & $0.08-0.17$ & 28 \\
\hline $\mathrm{C}_{2} \mathrm{H}_{6}$ & 774 & 147 & 748 & $403-1111$ & 51 & 756 & 251 & 792 & $384-1448$ & 58 & 922 & 232 & 908 & $641-1372$ & 28 \\
\hline $\mathrm{C}_{3} \mathrm{H}_{8}$ & 106 & 127 & 78 & $26-919$ & 51 & 97 & 81 & 73 & $7.5-369$ & 58 & 111 & 56 & 123 & 54-239 & 28 \\
\hline $\mathrm{C}_{2} \mathrm{H}_{2}$ & 433 & 138 & 390 & $94-874$ & 51 & 181 & 119 & 140 & $37-499$ & 58 & 141 & 103 & 171 & $60-413$ & 28 \\
\hline $\mathrm{C}_{2} \mathrm{H}_{4}$ & 79 & 77 & 46 & $7-363$ & 51 & 25 & 37 & 16 & $2-178$ & 51 & 13 & 13 & 7 & $3-47$ & 25 \\
\hline $\mathrm{CH}_{3} \mathrm{Cl}$ & 666 & 21 & 667 & $592-702$ & 51 & 655 & 35 & 638 & $602-731$ & 58 & 662 & 37 & 656 & $618-763$ & 28 \\
\hline $\mathrm{C}_{2} \mathrm{Cl}_{4}$ & 7.4 & 13 & 3.5 & $2.9-87$ & 51 & 2.6 & 14 & 3.2 & $11-5.0$ & 58 & 3.0 & 24 & 3.1 & $10-10$ & 28 \\
\hline CFC-11 & 252.0 & 2.2 & 252.1 & $2459-257.1$ & 51 & 253.9 & 2.6 & 253.2 & $250.1-2657$ & 58 & 258.9 & 4.0 & 258.0 & $250.7-266.3$ & 28 \\
\hline CFC-12 & 488.7 & 4.4 & 486.6 & $481.2-5076$ & 51 & 488.3 & 3.1 & 488.0 & $483.1-498.1$ & 58 & 494.1 & 45 & 493.5 & $4864-503.7$ & 28 \\
\hline CFC-113 & 76.5 & 0.72 & 76.3 & $74.5-78.6$ & 51 & 76.7 & 0.85 & 765 & $75.3-80.8$ & 58 & 78.7 & 1.2 & 78.3 & $75.7-80.4$ & 28 \\
\hline $\mathrm{CH}_{3} \mathrm{CCl}_{3}$ & 123 & 3.6 & 122 & $110-140$ & 51 & 120 & 4.7 & 121 & $106-134$ & 58 & 123 & 4.2 & 122 & $116-130$ & 28 \\
\hline $\mathrm{CCl}_{4}$ & 99 & 1.8 & 99 & $92-103$ & 51 & 96 & 5.0 & 97 & $72-100$ & 58 & 97 & 3.8 & 98 & $88-102$ & 28 \\
\hline $\mathrm{C}_{6} \mathrm{H}_{6}$ & 80 & 23 & 73 & $16-164$ & 51 & 22 & 28 & 12 & $2.4-114$ & 53 & 16 & 20 & 8.8 & $2.8-69$ & 28 \\
\hline $\mathrm{HCOOH}$ & 1802 & 266 & 1847 & $1502-2369$ & 23 & 418 & 95 & 385 & $215-611$ & 47 & 253 & 174 & 220 & $93-708$ & 67 \\
\hline $\mathrm{CH}_{3} \mathrm{COOH}$ & 1995 & 162 & 1983 & $1765-2373$ & 23 & 1139 & 360 & 1080 & $615-2086$ & 47 & 704 & 163 & 650 & $490-1117$ & 66 \\
\hline $\mathrm{H}_{2} \mathrm{O}_{2}$ & 4935 & 2519 & 3396 & $716-11,418$ & 40 & 442 & 1595 & 335 & $84-14,297$ & 80 & 338 & 376 & 250 & $85-1569$ & 87 \\
\hline $\mathrm{CH}_{3} \mathrm{OOH}$ & 857 & 152 & 727 & $581-1196$ & 40 & 94 & 154 & 80 & $16-840$ & 62 & 175 & 150 & 135 & $15-393$ & 46 \\
\hline $\mathrm{CH}_{2} \mathrm{O}$ & 387 & 119 & 402 & $214-721$ & 22 & 105 & 130 & 75 & $36-402$ & 8 & 75 & 29 & 60 & $43-179$ & 48 \\
\hline Aerosols & 975 & 542 & 977 & $118-3050$ & 61 & 43 & 81 & 24 & $94-822$ & 145 & 62 & 82 & 53 & $12-902$ & 169 \\
\hline
\end{tabular}

Mixing ratios are stated in parts per trillion by volume (pptv); except for $\mathrm{CO}, \mathrm{CH}_{4}, \mathrm{~N}_{2} \mathrm{O}$ and $\mathrm{O}_{3}$ that are in parts per billion by volume ( $\mathrm{ppbv}$ ); and $\mathrm{CO}$ in parts per million by volume (ppmv), s.d. states the 1 standard deviation. $\mathrm{C}_{2} \mathrm{H}_{2} / \mathrm{CO}$ ratio is stated in pptv/ppbv; and aerosols are stated in number per cubic centimeter for $0.12-$ to $3.1-\mu \mathrm{m}$ diameter range

enhanced about $10 \%$. There was good correlation between mixing ratios of $\mathrm{CO}$ and $\mathrm{CH}_{3} \mathrm{Cl}$ (Figure 5), indicative of a biomass burning source for the combustion products in these air parcels.

An interesting feature of the data was the low $\mathrm{CO}$ and $\mathrm{CO}_{2}$ but elevated $\mathrm{CH}_{4}$ mixing ratios in some air parcels sampled at high altitude. Overall, there was a vertical gradient in the mixing ratio of $\mathrm{CH}_{4}$ of $+2.3 \mathrm{ppbv} \mathrm{km}^{-1}$ over the South Atlantic basin [Bartlett et al., this issue]. A possible explanation would be convective transport from ground level to the upper troposphere of air parcels from over a large wetland area such as the Pantanal in southwestern Brazil. Aged Pacific air parcels flowing down the eastern slope of the Andes (low $\mathrm{CO}$ ) could accumulate $\mathrm{CH}_{4}$ released from natural methanogenic processes while $\mathrm{CO}_{2}$ would be consumed by photosynthetic activity. Air mass back trajectories commonly originated over southwestern Brazil, and convective activity was frequent [Pickering et al., this issue]. Furthermore, the longitudinal distribution of $\mathrm{CH}_{4}$ over the South Atlantic basin suggests that $\mathrm{CH}_{4}$ inputs were greater from South America than from Africa [Bartlett et al., this issue].

Another indication that convective activity might be involved comes from the $\mathrm{NO}$ and $\mathrm{NO}_{\mathrm{x}}$ data. Mixing ratios of $\mathrm{NO}$ and
$\mathrm{NO}_{\mathrm{x}}$ were quite elevated $(100-250 \mathrm{pptv})$ in near-surface air parcels apparently influenced by natural biogenic processes [Harris et al., this issue; Levine et al., this issue]. Lightning could also have contributed to the elevated mixing ratios of NO and $\mathrm{NO}_{\mathrm{x}}$ at high altitude, preserving the characteristically low mixing ratios of $\mathrm{CO}$.

Compared to the western basin of the tropical South Atlantic, a fairly extensive sampling of continental outflow was obtained over the eastern basin (Figure 4). As was found over the western basin, mixing ratios of $\mathrm{CO}$ and $\mathrm{CH}_{3} \mathrm{Cl}$ were correlated for $\mathrm{CH}_{3} \mathrm{Cl}$ mixing ratios in the range $600-700 \mathrm{pptv}$ (Figure 5). The reason for the departures from the primary relationship between these species is unclear, particularly since smoldering fires have high emissions of both $\mathrm{CO}$ and $\mathrm{CH}_{3} \mathrm{Cl}$ [Lobert et al., 1991; Blake et $a l$., this issue]. The data in the divergent arms of the plots shown in Figure 5 are from several different flights and altitudes. Thus they are not confined to a single flight or air parcel.

The vertical distribution of combustion-derived insoluble species over the eastern basin indicates that the tropospheric column from 2 to $13 \mathrm{~km}$ was predominately fumigated with biomass fire emissions. Natural biospheric sources might also be important for alkene species, especially $\mathrm{C}_{2} \mathrm{H}_{4}$ [Rudolph et al., 
Table 3. Mixing Ratios of Principal Species Measured in Continental Outflow Over the Eastern South Atlantic Ocean

\begin{tabular}{|c|c|c|c|c|c|c|c|c|c|c|c|c|c|c|c|}
\hline \multirow[b]{2}{*}{ Species } & \multicolumn{5}{|c|}{$15-49 \mathrm{~km}$} & \multicolumn{5}{|c|}{$5-99 \mathrm{~km}$} & \multicolumn{5}{|c|}{$10-13 \mathrm{~km}$} \\
\hline & Mean & s.d. & Median & Range & $\mathbf{N}$ & Mean & s.d. & Median & Range & $\mathbf{N}$ & Mean & s.d. & Median & Range & $\mathrm{N}$ \\
\hline No & 22 & 10 & 19 & $12-37$ & 101 & 51 & 41 & 37 & $14-353$ & 160 & 200 & 140 & 135 & $19-805$ & 676 \\
\hline $\mathrm{NO}_{\mathrm{x}}$ & 71 & 25 & 59 & $37-136$ & 93 & 98 & 66 & 54 & $40-533$ & 107 & 221 & 145 & 151 & $19-942$ & 670 \\
\hline $\mathrm{HNO}_{3}$ & 411 & 168 & 445 & $152-973$ & 67 & 119 & 55 & 140 & $14-271$ & 57 & 71 & 31 & 85 & $14-180$ & 342 \\
\hline PAN & 294 & 336 & 230 & $10-1488$ & 34 & 302 & 163 & 300 & $85-1123$ & 48 & 249 & 160 & 265 & $82-2184$ & 230 \\
\hline$\Sigma \mathrm{NO}_{\mathrm{n}}$ & 588 & 334 & 522 & $213-2113$ & 66 & 368 & 185 & 338 & $100-1123$ & 75 & 335 & 207 & 277 & $99-2376$ & 466 \\
\hline $\mathrm{O}_{3}$ & 61 & 62 & 63 & $47-80$ & 122 & 74 & 12 & 73 & $55-102$ & 186 & 73 & 14 & 71 & $44-105$ & 867 \\
\hline $\mathrm{CO}$ & 129 & 42 & 108 & $80-198$ & 122 & 101 & 15 & 99 & $75-140$ & 180 & 99 & 15 & 95 & $69-150$ & 860 \\
\hline $\mathrm{CH}_{4}$ & 1699 & 60 & 1701 & $1684-1719$ & 122 & 1710 & 91 & 1706 & $1694-1732$ & 165 & 1717 & 73 & 1717 & $1696-1741$ & 857 \\
\hline $\mathrm{CO}_{2}$ & 356.8 & 2.3 & 3566 & $353.3-360.0$ & 116 & 3553 & 076 & 3553 & $3530-3581$ & 170 & 3545 & 1.3 & 354.4 & $349.9-357.8$ & 812 \\
\hline $\mathrm{N}_{2} \mathrm{O}$ & 309.9 & 0.31 & 310.1 & $3094-310.8$ & 58 & 309.8 & 0.39 & 309.8 & $308.5-3108$ & 161 & 310.0 & 0.58 & 310.0 & $308.0-310.9$ & 713 \\
\hline $\mathrm{C}_{2} \mathrm{H}_{2} / \mathrm{CO}$ & 1.1 & 0.60 & 1.0 & $0.51-2.1$ & 56 & 1.2 & 0.23 & 1.1 & $0.71-1.8$ & 82 & 1.2 & 025 & 1.1 & $0.61-2.0$ & 359 \\
\hline $\mathrm{C}_{3} \mathrm{H}_{8} / \mathrm{C}_{2} \mathrm{H}_{6}$ & 0.05 & 0.02 & 0.06 & $0.02-0.09$ & 56 & 0.08 & 002 & 0.07 & $0.04-0.16$ & 85 & 0.10 & 0.04 & 0.10 & $0.05-0.27$ & 362 \\
\hline $\mathrm{C}_{2} \mathrm{H}_{6}$ & 574 & 170 & 635 & $430-1015$ & 56 & 669 & 152 & 720 & $441-982$ & 61 & 683 & 146 & 710 & $394-1773$ & 362 \\
\hline $\mathrm{C}_{3} \mathrm{H}_{8}$ & 31 & 23 & 35 & 8.2-79 & 56 & 59 & 29 & 48 & $25-134$ & 61 & 69 & 44 & 55 & $27-484$ & 362 \\
\hline $\mathrm{C}_{2} \mathrm{H}_{2}$ & 140 & 117 & 160 & $39-388$ & 56 & 120 & 40 & & $61-246$ & 61 & 121 & 40 & 125 & $53-246$ & 362 \\
\hline $\mathrm{C}_{2} \mathrm{H}_{4}$ & 19 & 20 & 30 & $3-81$ & 53 & 10 & 9 & 12 & $3-66$ & 46 & 9 & 3 & 9 & $3-22$ & 274 \\
\hline $\mathrm{CH}_{3} \mathrm{Cl}$ & 648 & 26 & 655 & $615-716$ & 56 & 668 & 31 & 660 & $610-812$ & 61 & 667 & 43 & 670 & $621-880$ & 362 \\
\hline $\mathrm{C}_{2} \mathrm{Cl}_{4}$ & 3.3 & 050 & 3.1 & $2.4-4.2$ & 49 & 3.0 & 0.40 & 30 & $2.1-4.1$ & 43 & 3.0 & 0.60 & 2.9 & $1.6-5.1$ & 340 \\
\hline CFC-11 & 259.9 & 2.3 & 258.8 & $255.2-264.0$ & 56 & 2613 & 26 & 2605 & $256.8-267.3$ & 52 & 260.2 & 2.5 & 260.1 & $254.6-268.9$ & 340 \\
\hline $\mathrm{CFC}-12$ & 491.6 & 3.7 & 492.0 & $485.6-503.5$ & 56 & 4926 & 30 & 493.1 & $485.0-497.9$ & 52 & 493.9 & 3.4 & 495.0 & $485.0-506.1$ & 340 \\
\hline CFC-113 & 79.9 & 0.71 & 789 & $779-81.7$ & 56 & 79.3 & 0.97 & 791 & $77.2-812$ & 52 & 78.8 & 1.6 & 790 & $72.7-87.9$ & 340 \\
\hline $\mathrm{CH}_{3} \mathrm{CCl}_{3}$ & 129 & 2.9 & 130 & $121-134$ & 56 & 125 & 3.7 & 125 & $117-133$ & 50 & 122 & 74 & 123 & $71-135$ & 340 \\
\hline $\mathrm{CCl}_{4}$ & 103 & 13 & 1015 & $100-106$ & 56 & 100 & 39 & 1022 & $84-106$ & 61 & 97 & 88 & 97.6 & $71-105$ & 362 \\
\hline $\mathrm{C}_{6} \mathrm{H}_{6}$ & 30 & 30 & 20 & $66-124$ & 55 & 20 & 75 & 22 & $7.2-41$ & 58 & 17 & 77 & 17 & $4.5-51$ & 317 \\
\hline $\mathrm{HCOOH}$ & 2187 & 1838 & 1560 & $230-6966$ & 61 & 905 & 554 & 677 & $304-3581$ & 57 & 638 & 281 & 675 & $238-3664$ & 342 \\
\hline $\mathrm{CH}_{3} \mathrm{COOH}$ & 2785 & 2554 & 2155 & $487-12,254$ & 61 & 2834 & 1603 & 2530 & $767-7793$ & 57 & 2788 & 1630 & 2250 & $658-9213$ & 342 \\
\hline $\mathrm{H}_{2} \mathrm{O}_{2}$ & 2940 & 2147 & 617 & $28-7818$ & 79 & 481 & 451 & 329 & $26-2412$ & 85 & 108 & 94 & 93 & $10-498$ & 376 \\
\hline $\mathrm{CH}_{3} \mathrm{OOH}$ & 828 & 441 & 668 & $13-1547$ & 80 & 105 & 79 & 65 & $10-523$ & 85 & 55 & 63 & 48 & $13-376$ & 233 \\
\hline $\mathrm{CH}_{2} \mathrm{O}$ & 132 & 89 & 92 & $5.0-323$ & 32 & 40 & 32 & 53 & $6.0-83$ & 7 & 87 & 73 & 69 & $5.0-284$ & 34 \\
\hline Aerosols & 520 & 472 & 175 & $7.5-1457$ & 94 & 68 & 50 & 51 & 7.3-294 & 151 & 23 & 17 & 14 & $34-115$ & 727 \\
\hline
\end{tabular}

Mixing ratios are stated in parts per trillion by volume (pptv); except for $\mathrm{CO}, \mathrm{CH}_{4}, \mathrm{~N}_{2} \mathrm{O}$ and $\mathrm{O}_{1}$ that are in parts per billion by volume (ppbv), and $\mathrm{CO}_{2}$ in parts per million by volume (ppmv); s.d. states the 1 standard deviation $\mathrm{C}_{2} \mathrm{H}_{2} / \mathrm{CO}$ ratio is stated in pptv/ppbv; and aerosols are stated in number per cubic centimeter for $0.12-$ to $31-\mu \mathrm{m}$ diameter range.

1992]. Previous observations from the space shuttle identified the South Atlantic region as having elevated $\mathrm{CO}$ mixing ratios of $80-100 \mathrm{ppbv}$ at this time of the year [Newell et al., 1988]. The TRACE A airborne measurements appear to confirm the suspicions of Newell et al. [1988] that biomass burning is the source of much of the enhanced tropospheric $\mathrm{CO}$ during the austral springtime.

Within plume layers coming directly off the African continent, there were significant enrichments of the water-soluble gases $\mathrm{H}_{2} \mathrm{O}_{2}, \mathrm{CH}_{3} \mathrm{OOH}, \mathrm{CH}_{2} \mathrm{O}, \mathrm{HCOOH}, \mathrm{CH}_{3} \mathrm{COOH}$, and $\mathrm{HNO}_{3}$. This characteristic was also prevalent in the air parcels sampled over the western basin. Outflow plumes coming off southern Africa were typically centered around $4 \mathrm{~km}$ altitude. This feature is illustrated in Figure 6 using observations obtained on mission 14 flown over the eastern South Atlantic basin. The relatively small mixing ratios of $\mathrm{NO}$ and $\mathrm{NO}_{\mathrm{x}}(<100 \mathrm{pptv})$ and large ratios of $\mathrm{HNO}_{3}(\leq 1000 \mathrm{pptv})$ indicate photochemical aging of these plumes of the order of a few days. Nitric acid usually comprised $70 \%$ or more of the $\Sigma \mathrm{NO}_{\mathrm{yi}}$ in these plumes. Mixing ratios of $\mathrm{O}_{3}$ within the plumes were usually less than $70 \mathrm{ppbv}$ compared to up to $105 \mathrm{ppbv}$ in air parcels over the South Atlantic. Peroxide and carboxylic acid species commonly approached or exceeded $10 \mathrm{ppbv}$ within the plume layers. Previous measurements of carboxylic acids over the Congo region of Africa during the dry season indicated an important biomass burning source for these species [Helas et al., 1992]. It appears that a similar argument can be made for the peroxide species [Heikes et al., 1996].

A noticeable characteristic of the chemistry over the tropical South Atlantic was the elevated mixing ratios of water-soluble gases and aerosol particles (0.12- to 3.1- $\mu \mathrm{m}$ diameter) below 6 $\mathrm{km}$ compared to above this altitude (Figures $3 \mathrm{c}$ and $4 \mathrm{c}$ ). Insoluble and/or long-lived (i.e., atmospheric lifetime $>1$ month) gases showed a much more uniform distribution from 1 to 12.5 $\mathrm{km}$ altitude (Figures 3a, 3b, 4a, and 4b). A possible explanation for this is that the transport of species to the middle-to-upper troposphere over the continents occurred primarily in wet convective systems where soluble gases and aerosol particles were effectively scavenged. The outflow at altitudes below $6 \mathrm{~km}$ appeared to be largely coupled to synoptic flow patterns and the 

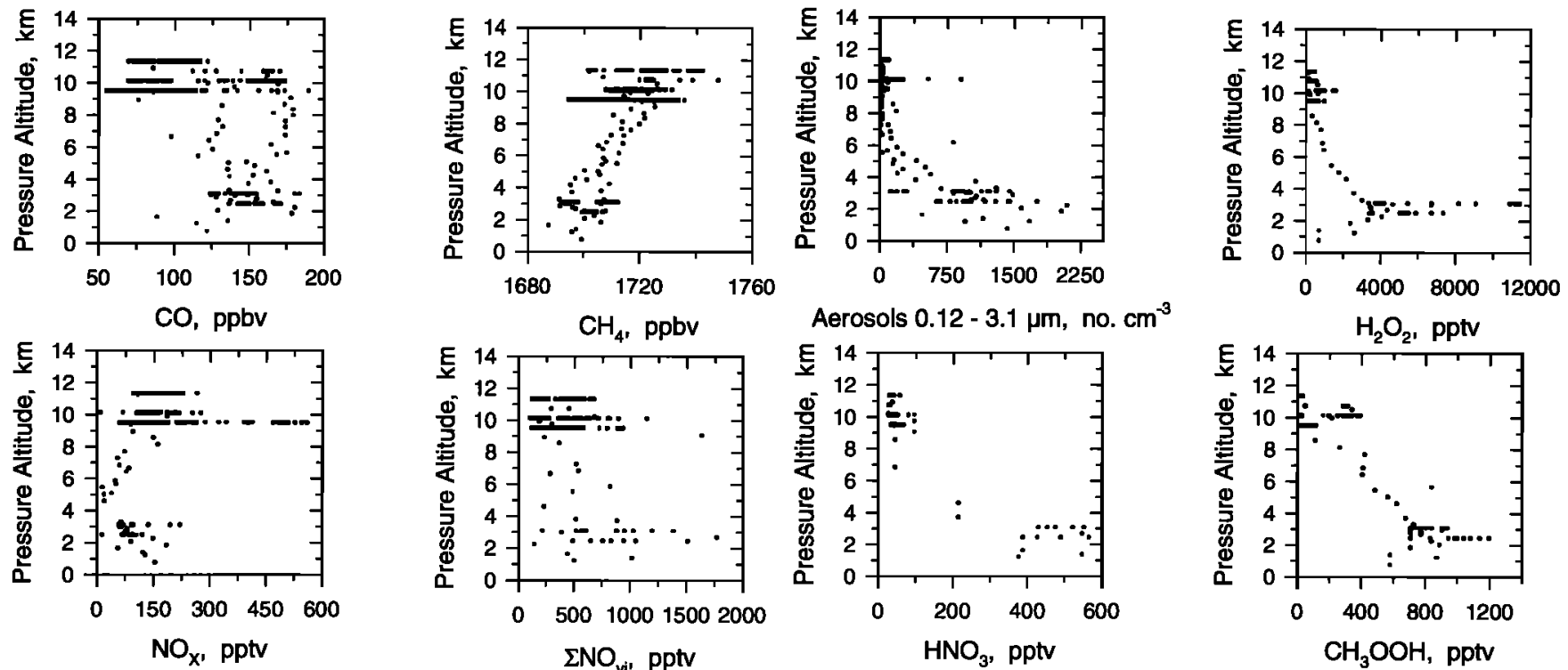

Aerosols $0.12-3.1 \mu \mathrm{m}$, no. $\mathrm{cm}^{-3}$
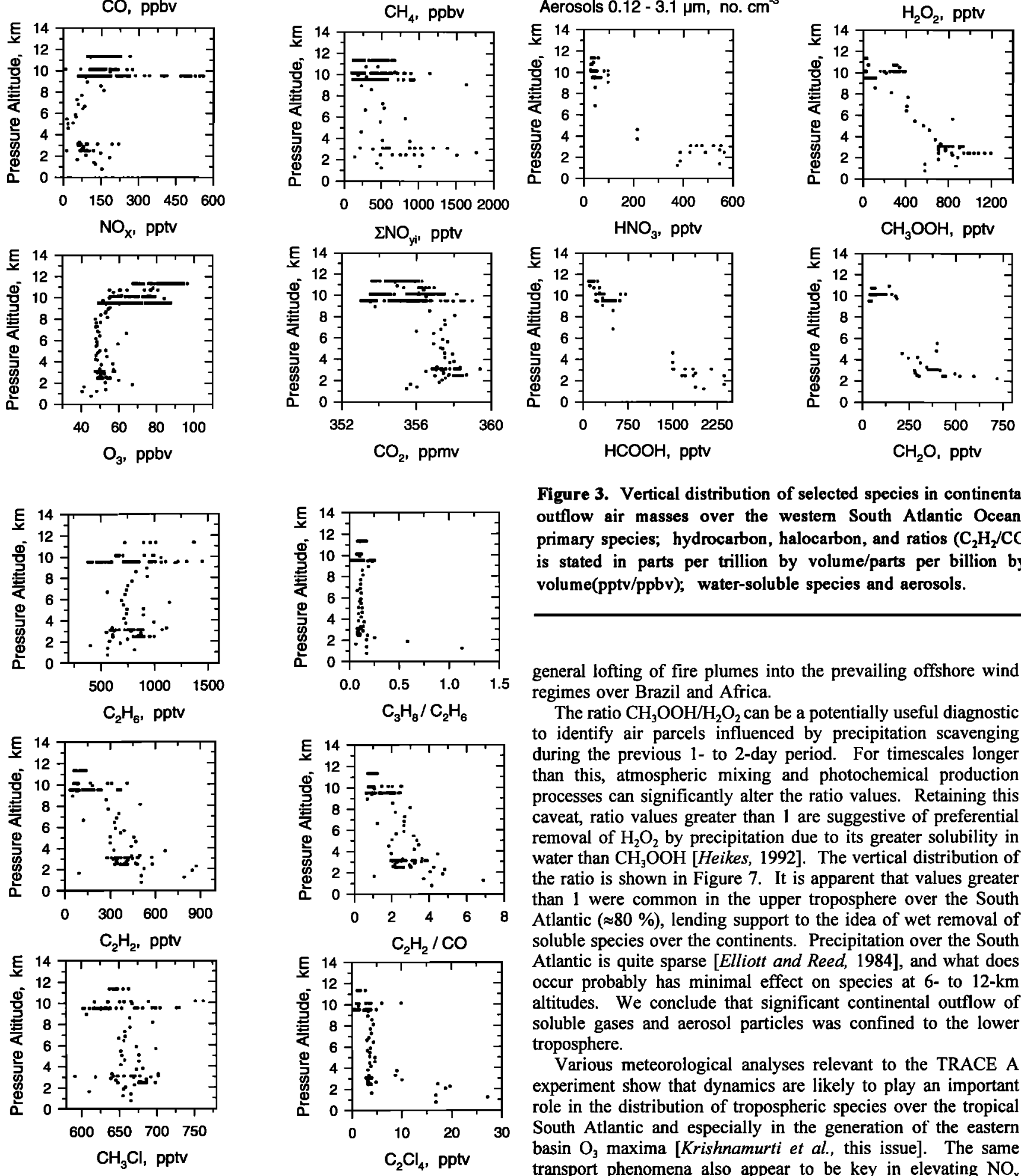

Figure 3. Vertical distribution of selected species in continental outflow air masses over the westem South Atlantic Ocean: primary species; hydrocarbon, halocarbon, and ratios $\left(\mathrm{C}_{2} \mathrm{H}_{2} / \mathrm{CO}\right.$ is stated in parts per trillion by volume/parts per billion by volume(pptv/ppbv); water-soluble species and aerosols.

general lofting of fire plumes into the prevailing offshore wind regimes over Brazil and Africa.

The ratio $\mathrm{CH}_{3} \mathrm{OOH} / \mathrm{H}_{2} \mathrm{O}_{2}$ can be a potentially useful diagnostic to identify air parcels influenced by precipitation scavenging during the previous 1- to 2-day period. For timescales longer than this, atmospheric mixing and photochemical production processes can significantly alter the ratio values. Retaining this caveat, ratio values greater than 1 are suggestive of preferential removal of $\mathrm{H}_{2} \mathrm{O}_{2}$ by precipitation due to its greater solubility in water than $\mathrm{CH}_{3} \mathrm{OOH}$ [Heikes, 1992]. The vertical distribution of the ratio is shown in Figure 7. It is apparent that values greater than 1 were common in the upper troposphere over the South Atlantic $(\approx 80 \%)$, lending support to the idea of wet removal of soluble species over the continents. Precipitation over the South Atlantic is quite sparse [Elliott and Reed, 1984], and what does occur probably has minimal effect on species at 6- to $12-\mathrm{km}$ altitudes. We conclude that significant continental outflow of soluble gases and aerosol particles was confined to the lower troposphere.

Various meteorological analyses relevant to the TRACE A experiment show that dynamics are likely to play an important role in the distribution of tropospheric species over the tropical South Atlantic and especially in the generation of the eastern basin $\mathrm{O}_{3}$ maxima [Krishnamurti et al., this issue]. The same transport phenomena also appear to be key in elevating $\mathrm{NO}_{\mathbf{x}}$ mixing ratios in this same region [Smyth et al., this issue]. The 


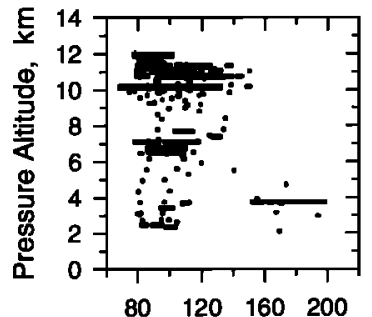

CO, ppbv

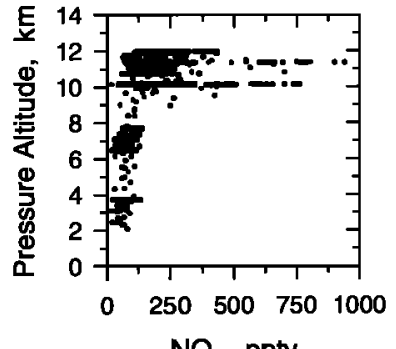

$\mathrm{NO}_{\mathrm{x}}, \mathrm{pptv}$
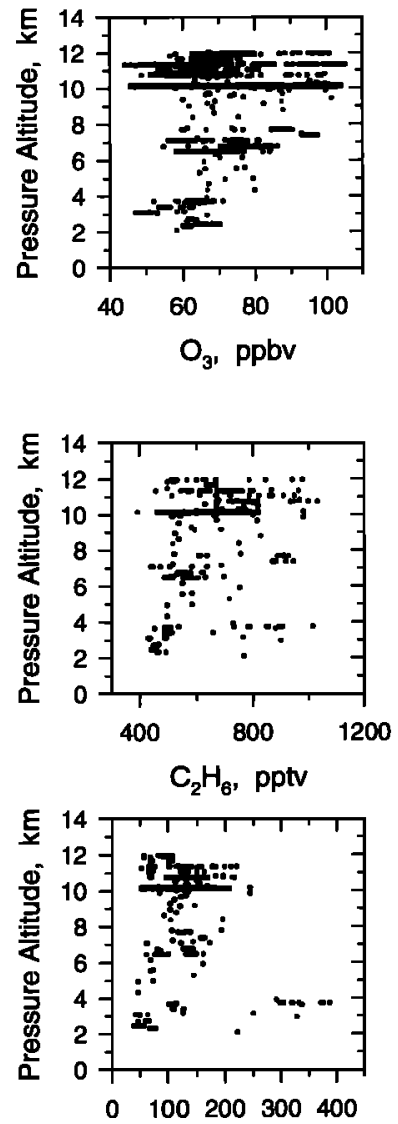

$\mathrm{C}_{2} \mathrm{H}_{2}$, pptv

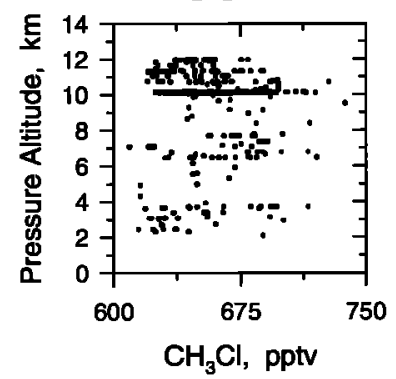

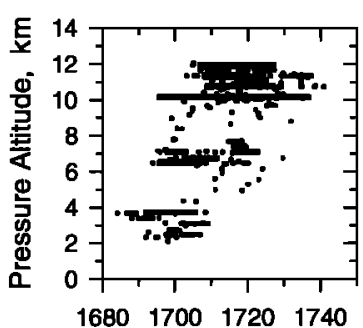

$\mathrm{CH}_{4}$, ppbv

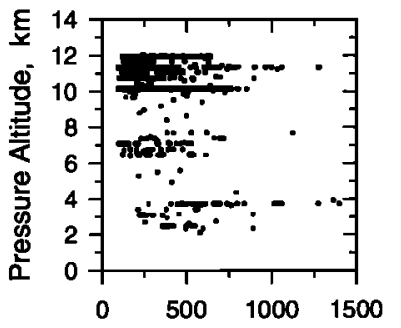

$\mathrm{NNO}_{\text {yil }} \mathrm{pptv}$
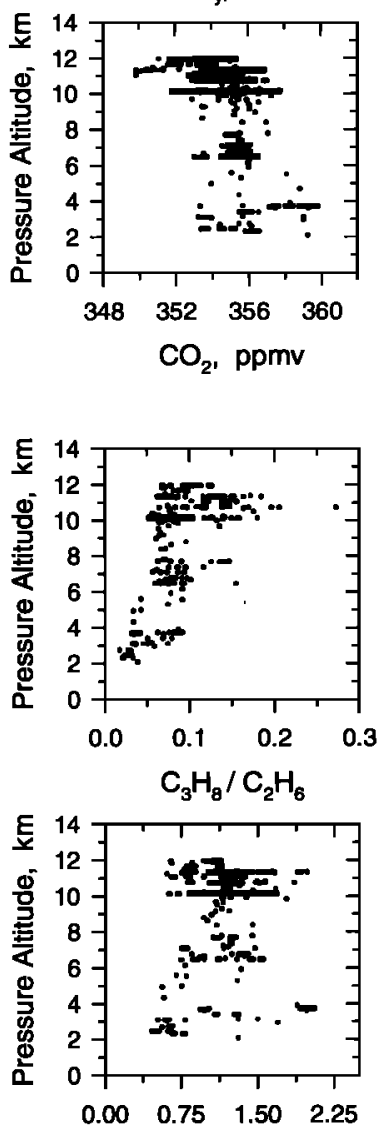

$\mathrm{C}_{2} \mathrm{H}_{2} / \mathrm{CO}$

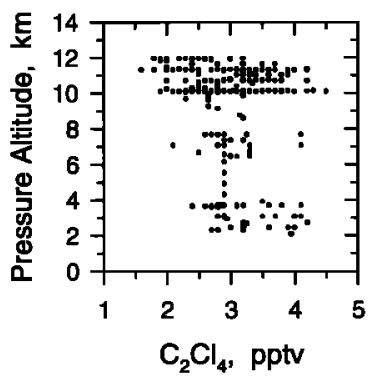

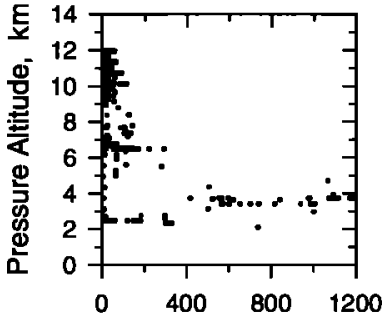

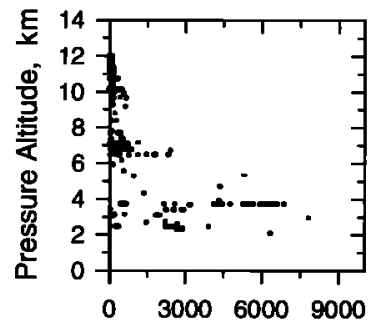

Aerosols 0.12 - $3.1 \mu \mathrm{m}, \mathrm{no} . \mathrm{cm}^{-3}$
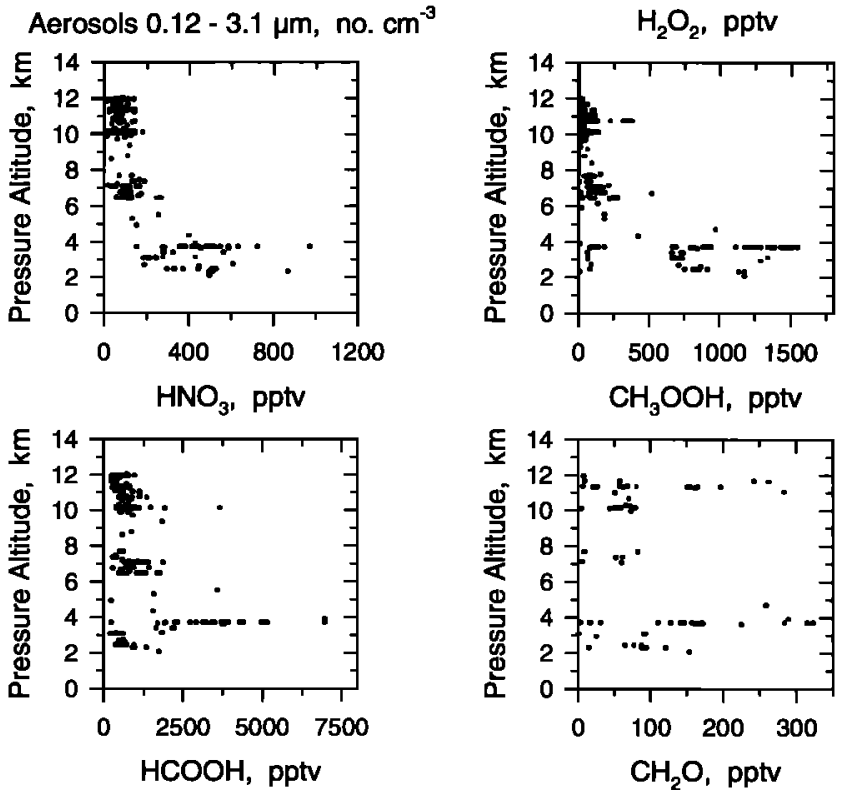

Figure 4. Vertical distribution of selected species in continental outflow air masses over the eastem South Atlantic Ocean: primary species; hydrocarbon, halocarbon, and ratios $\left(\mathrm{C}_{2} \mathrm{H}_{2} / \mathrm{CO}\right.$ is stated in $\mathrm{pptv} / \mathrm{ppbv}$ ); water-soluble species and aerosols.

convergence of air parcels in the upper troposphere over the eastern basin of the tropical South Atlantic appears to be driven by large-scale circulations bringing air to this region from over Brazil, central and southern Africa, and even the Asian monsoon area [Krishnamurti et al., this issue].

Slow subsidence over the eastern South Atlantic basin promotes clear skies and an environment conducive to photochemical activity [Krishnamurti et al., 1993]. This subsidence undoubtedly plays a role in establishing and maintaining the rather uniform vertical distribution of long-lived species over this whole region. Horizontal injection of additional biomass burning products from the African continent, including water-soluble species and aerosol particles, is frequent below $6 \mathrm{~km}$ altitude. The deposition of aerosol particles and gaseous species like $\mathrm{HNO}_{3}$ may provide important nutrient inputs to oligotrophic South Atlantic and Indian Ocean surface waters [Moody et al., 1991]. Nitrogen is often a limiting nutrient in marine ecosystems [Paerl, 1985, 1993], and biomass burning emissions from the African continent are known to be especially nitrogen rich [Delmas, 1982].

\section{Aged Marine Air at 10-13 km Altitude: A Closer Look}

Nearly $50 \%$ of the air parcels sampled during TRACE A were classified as aged marine. These air parcels thus contributed in an important way to the large-scale chemistry of the troposphere over the tropical South Atlantic. Of particular interest is an 

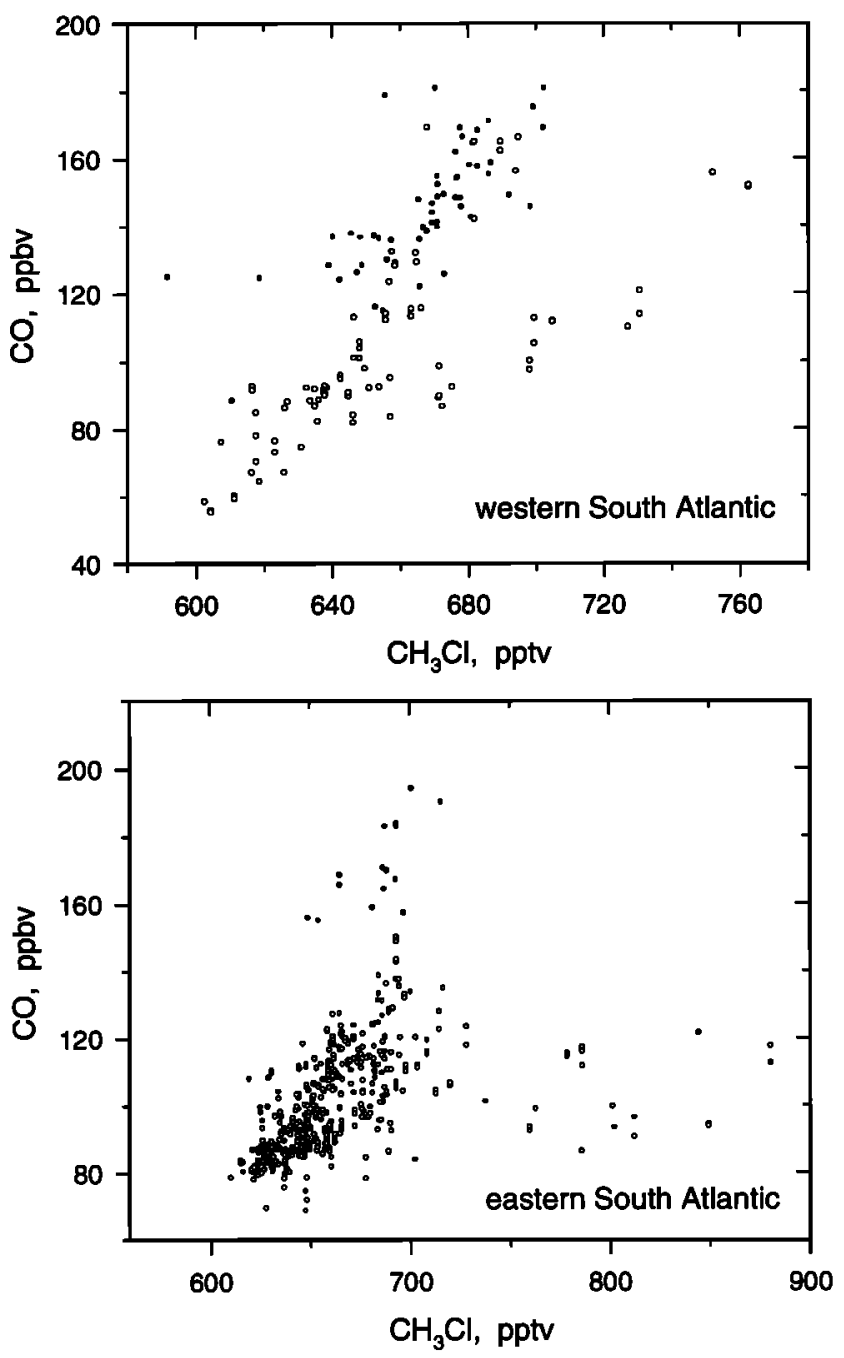

Figure 5. Relationship between $\mathrm{CO}$ and $\mathrm{CH}_{3} \mathrm{Cl}$ in continental outflow air masses over the tropical South Atlantic Ocean. The solid circles refer to data obtained at $0-5.9 \mathrm{~km}$ altitude and the open circles $6-12 \mathrm{~km}$. These correlations are evidence for a biomass buming source.

assessment of species sources in the $10-$ to $13-\mathrm{km}$ altitude range. Values of the ratios $\mathrm{C}_{2} \mathrm{H}_{2} / \mathrm{CO}$ and $\mathrm{C}_{3} \mathrm{H}_{8} / \mathrm{C}_{2} \mathrm{H}_{6}$ indicated that these air parcels were the least processed (i.e., source emissions influenced the least by photochemical aging and mixing process [McKeen and Liu, 1993]). It appears that subsidence then mixes these high-altitude air parcels downward producing compositionally similar but more processed air parcels (indicated by lower $\mathrm{C}_{2} \mathrm{H}_{2} / \mathrm{CO}$ and $\mathrm{C}_{3} \mathrm{H}_{8} / \mathrm{C}_{2} \mathrm{H}_{6}$ ratios) at lower altitudes.

The latitudinal distribution of selected species illustrates the dramatic influence on the chemistry from the convergence of various air parcels at high altitude over the tropical South Atlantic (Figure 8). These data were obtained at $10 \mathrm{~km}$ altitude during a transist flight between Ascension Island and Puerto Rico (Figure 1, mission 18). The sharp gradient in the mixing ratio of various species indicates that the Intertropical Convergence Zone (ITCZ) was crossed near $10^{\circ} \mathrm{N}$. In the southern hemisphere the enhanced mixing ratios of $\mathrm{CO}, \mathrm{PAN}, \mathrm{C}_{2} \mathrm{H}_{2}$, and $\mathrm{CH}_{3} \mathrm{Cl}$ are indicative of a iarge-scale influence of biomass fire emissions. The increased mixing ratios of $\mathrm{CH}_{4}$ and $\mathrm{C}_{2} \mathrm{Cl}_{4}$ in the northern hemisphere are presumably driven by larger sources there [Steele et al., 1992; Blake et al., 1996].
Close examination of the southern hemispheric data shown in Figure 8 suggests that this latitudinal survey crossed through several continental plumes of combustion-related emissions with parcels of air corresponding to our aged marine classification sampled in between. Within these plumes there was good correlation among $\mathrm{CO}, \mathrm{CH}_{4}, \mathrm{PAN}, \mathrm{C}_{2} \mathrm{H}_{2}$, and $\mathrm{CH}_{3} \mathrm{Cl}$. Backward trajectories indicated that the various plumes sampled on mission 18 had originated from over Africa or South America. Eventually, these plume features should disappear as they photochemically age and are turbulently mixed and diluted to form aged marine air over the tropical South Atlantic.

We explored various sources of species in high-altitude aged marine air parcels using a geographic depiction of the mixing
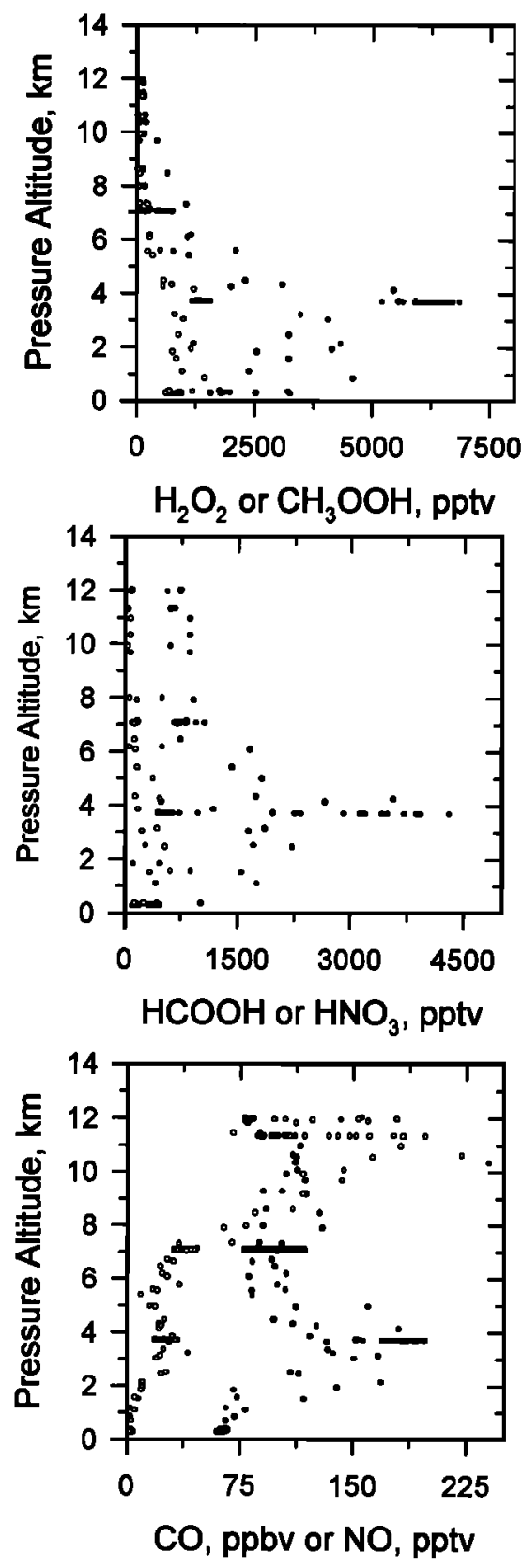

Figure 6. Vertical distribution of selected species in continental outflow air masses sampled duriug a spiral over the eastem South Atlantic basin on mission 14 (see Figure 1 for location). First species listed on each plot are shown by a solid circle and the second species as an open circle. 


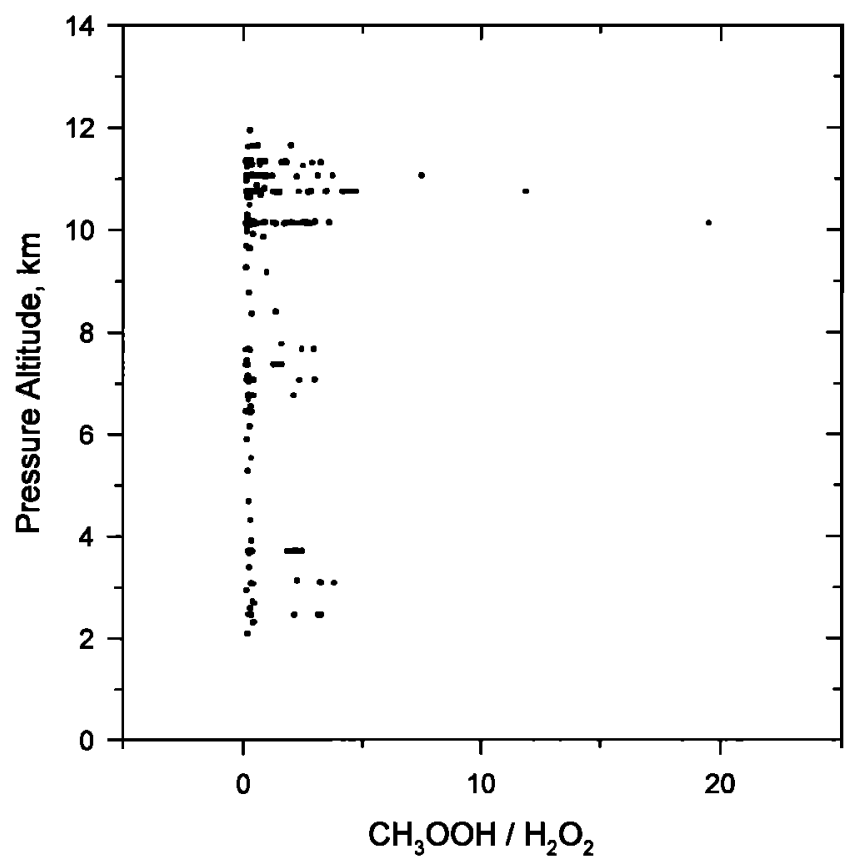

Figure 7. Distribution of the ratio $\mathrm{CH}_{3} \mathrm{OOH} / \mathrm{H}_{2} \mathrm{O}_{2}$ as a function of altitude in continental outflow air masses over the South Atlantic basin. Ratio values greater than 1 are indicative of air masses where $\mathrm{H}_{2} \mathrm{O}_{2}$ was preferentially removed by precipitation.

ratio as a function of latitude (Figure 9). Most species showed a rather uniform latitudinal distribution, demonstrating remarkable consistency in the composition of the high-altitude air parcels. The feature of depressed mixing ratios of some species (e.g., $\mathrm{CO}$, $\mathrm{CH}_{4}$, and $\mathrm{CO}_{2}$ ) in the $20^{\circ}-25^{\circ}$ latitude band may be related to stratospheric inputs or it simply may reflect very aged tropospheric air. These data were not removed from the aged marine classification by our filtering process for stratospheric air, but they typically exhibited $\mathrm{N}_{2} \mathrm{O}$ mixing ratios around $308 \mathrm{ppbv}$.

The latitudinal data also exhibit several other notable characteristics. For example, $\mathrm{O}_{3}$ mixing ratios showed an increasing trend that progressed from the equator to midlatitudes. Thus the in situ data suggest that the average mixing ratio of $\mathrm{O}_{3}$ in the vicinity of Ascension Island (Figure 1) was less than those observed off southern Africa (near Namibia, Angola, or Mozambique). Such details of the distribution of $\mathrm{O}_{3}$ are discussed in great detail in numerous companion papers in this issue.

Another feature of the high-altitude aged air over the tropical South Atlantic was the repetitive occurrence of large mixing ratios of NO (Figure 10). The mean lifetime of NO is estimated to be about 3.5 days at this altitude [Jacob et al., this issue]. This suggests that NO must be frequently replenished in high altitude air parcels to maintain a median mixing ratio of $130 \mathrm{pptv}$ (Table 1). It is unclear if the NO is replenished from biomass fire emissions, lightning, or recycled reactive nitrogen (Figure 10); [Jacob et al., this issue; Smyth et al., this issue].

Data were not obtained above $9 \mathrm{~km}$ altitude during mission 8 when aged Pacific air was sampled. However, the zenith-looking data for $\mathrm{O}_{3}$ and aerosols obtained remotely by the UV-DIAL (differential absorption lidar) system indicated that the uniform chemistry sampled below $9 \mathrm{~km}$ altitude probably extended up to at least $12 \mathrm{~km}$ [Browell et al., this issue]. In addition, during the initial leg of the mission 9 transit flight from Rio de Janeiro to Johannesburg we sampled aged Pacific air at $10 \mathrm{~km}$ altitude. These data are shown in Figure 9 at a latitude of about $36^{\circ}$ and $\mathrm{CO}$ mixing ratios $<75 \mathrm{ppbv}$ (data at bottom left corner of each plot). The composition of this aged Pacific air was very similar to the aged South Atlantic air sampled in the marine boundary on numerous missions [Heikes et al., this issue]. These air parcels thus define the chemistry of the "clean" aged air feeding into the tropical South Atlantic basin at all altitudes.

Comparison of this "clean" aged air with our aged marine classification indicates that source contributions to it must be frequent or large enough to maintain significantly enhanced mixing ratios of long-lived species over the South Atlantic. If biomass fire emissions were a dominant source of species at high
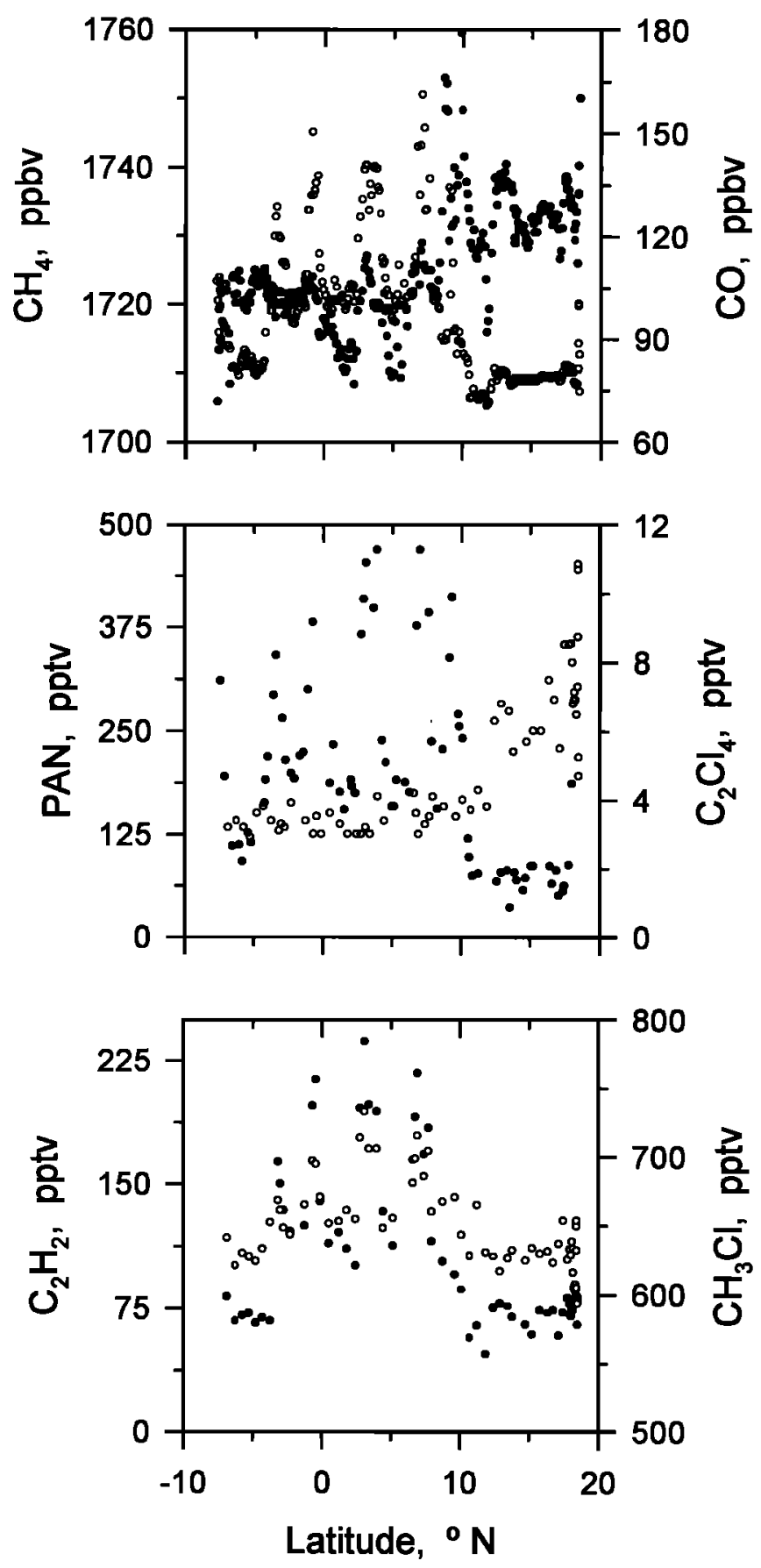

Figure 8. Latitudinal distribution of selected species at $10 \mathrm{~km}$ altitude between Ascension Island and Puerto Rico. Intertropical convergence zone was crossed near $10^{\circ} \mathrm{N}$, as evidenced by the sharp change in mixing ratio of the various species. Species shown on the left-hand side of plots are indicated by solid circles and those on the right-hand side by open circles. 

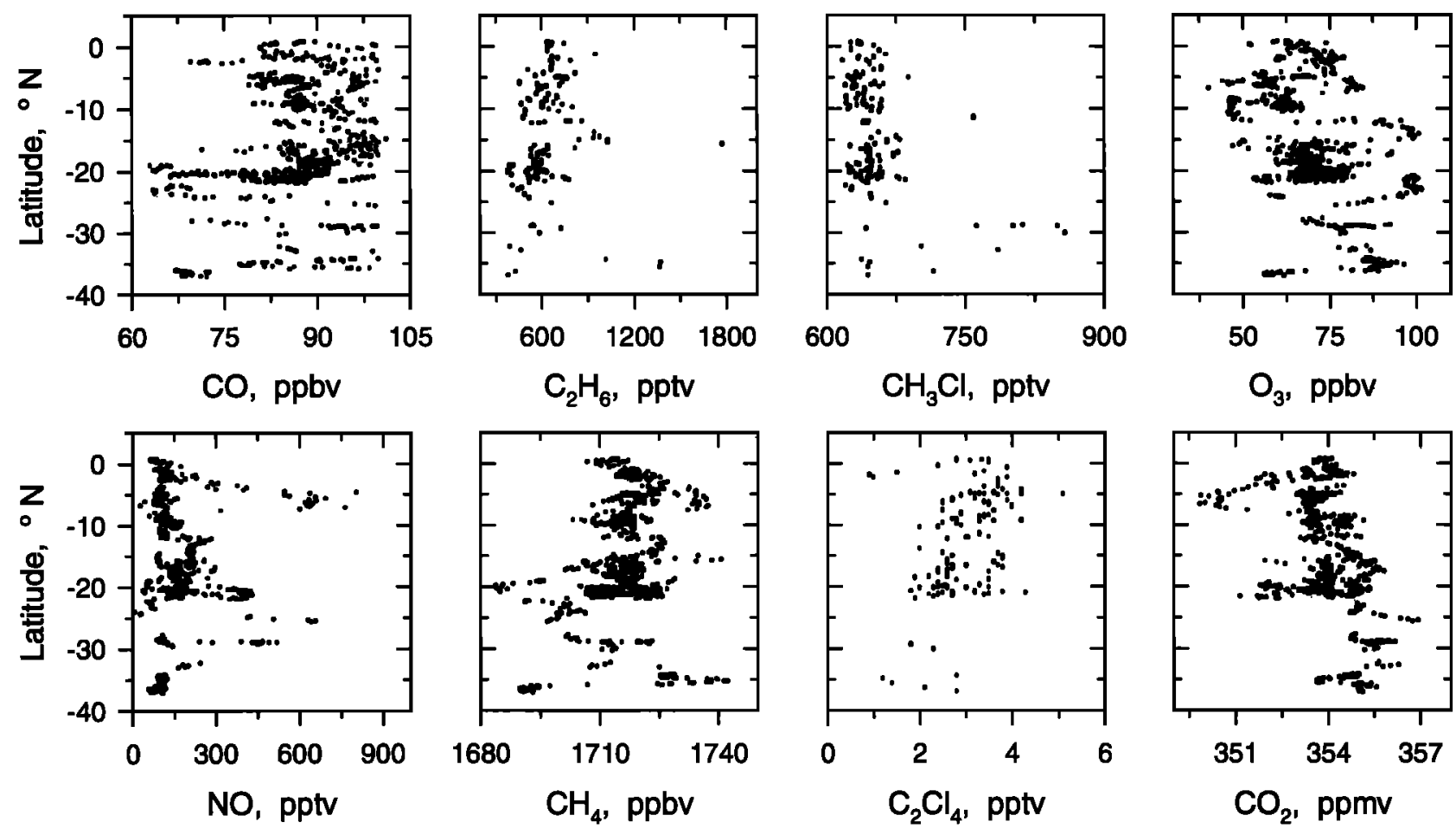

Figure 9. Latitudinal distribution of selscted species at $10-13 \mathrm{~km}$ altitude in aged marine air over the tropical South Atlantic Ocean.

altitude over the South Atlantic, the aged marine classification may reflect the net cumulative effect of the 1992 local dry season. Satellite observations indicated that the occurrence of biomass fires in Brazil and Africa was rapidly diminishing over the time span of the TRACE A expedition [Fishman et al., this issue].

There does not appear to be a straightforward method to identify definitively the sources of species in aged marine air over the South Atlantic. Backward trajectories indicated that the air parcels typically originated over all parts of central South America or Africa north of the equator (Figure 11). Dynamical studies also showed this, plus a possible teleconnection with the Indian monsoon region of southern Asia [Krishnamurti et al., this issue]. This opens a wide spectrum of source possibilities for many species, that include emissions from biomass fires, urban areas, wetlands, tropical forests, rice paddies (Southeast Asia), and air transported across the ITCZ from the northern hemisphere. Once air parcels carrying materials from various sources
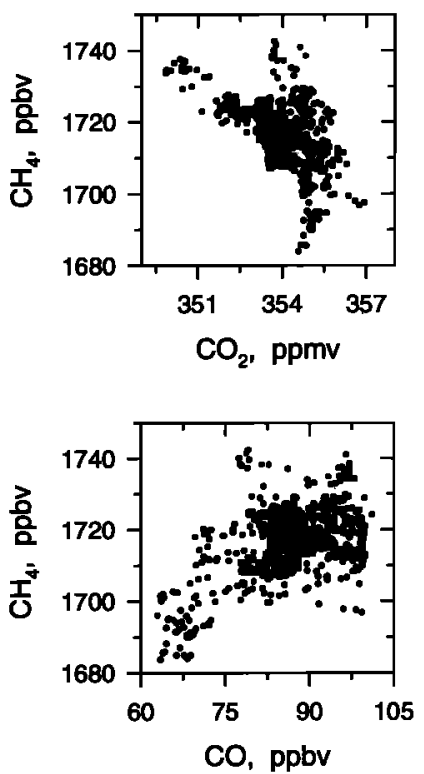
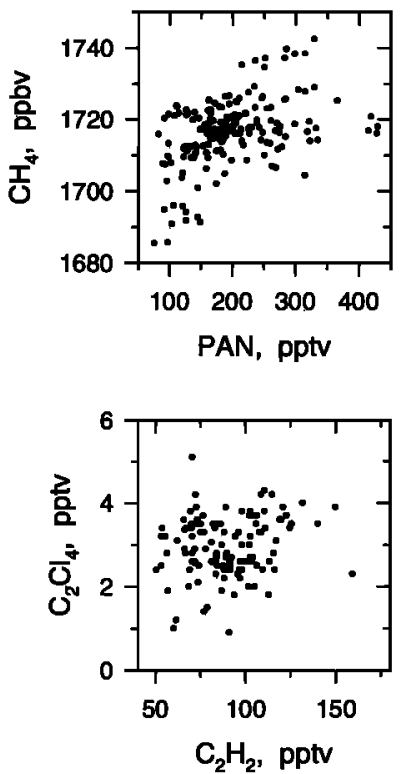
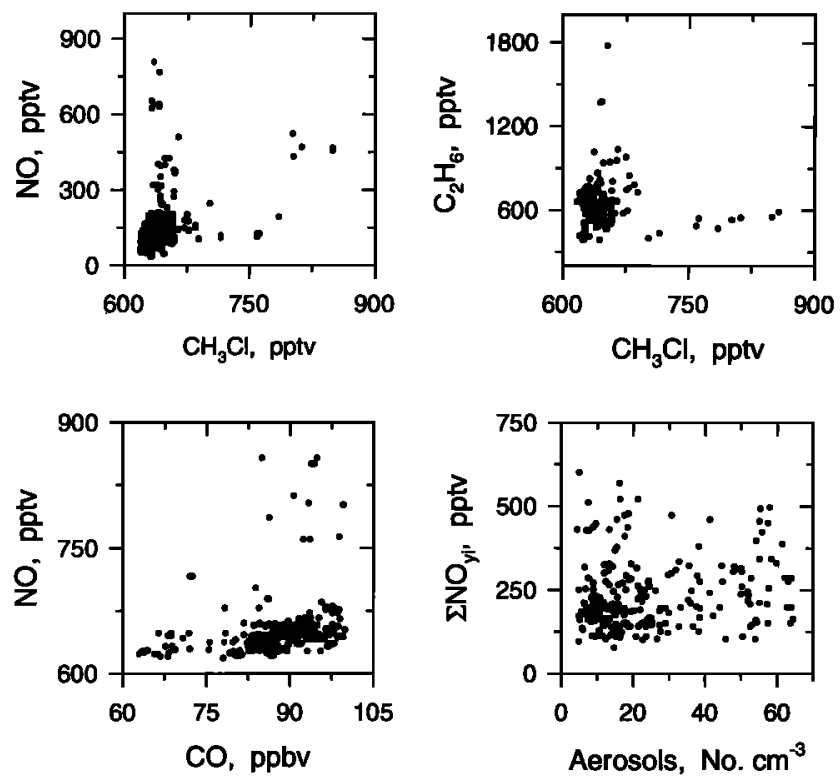

Figure 10. Relationship between selected species at $10-13 \mathrm{~km}$ altitude in aged marine air over the tropical South Atlantic Ocean. 
IRA JECIORY ANALYSIS FOR MISSION 13,14 THETA $=348 \mathrm{~K}$

START - DOZ OO OCI $92 \quad$ FINISH $-12 Z 14$ OCT 92
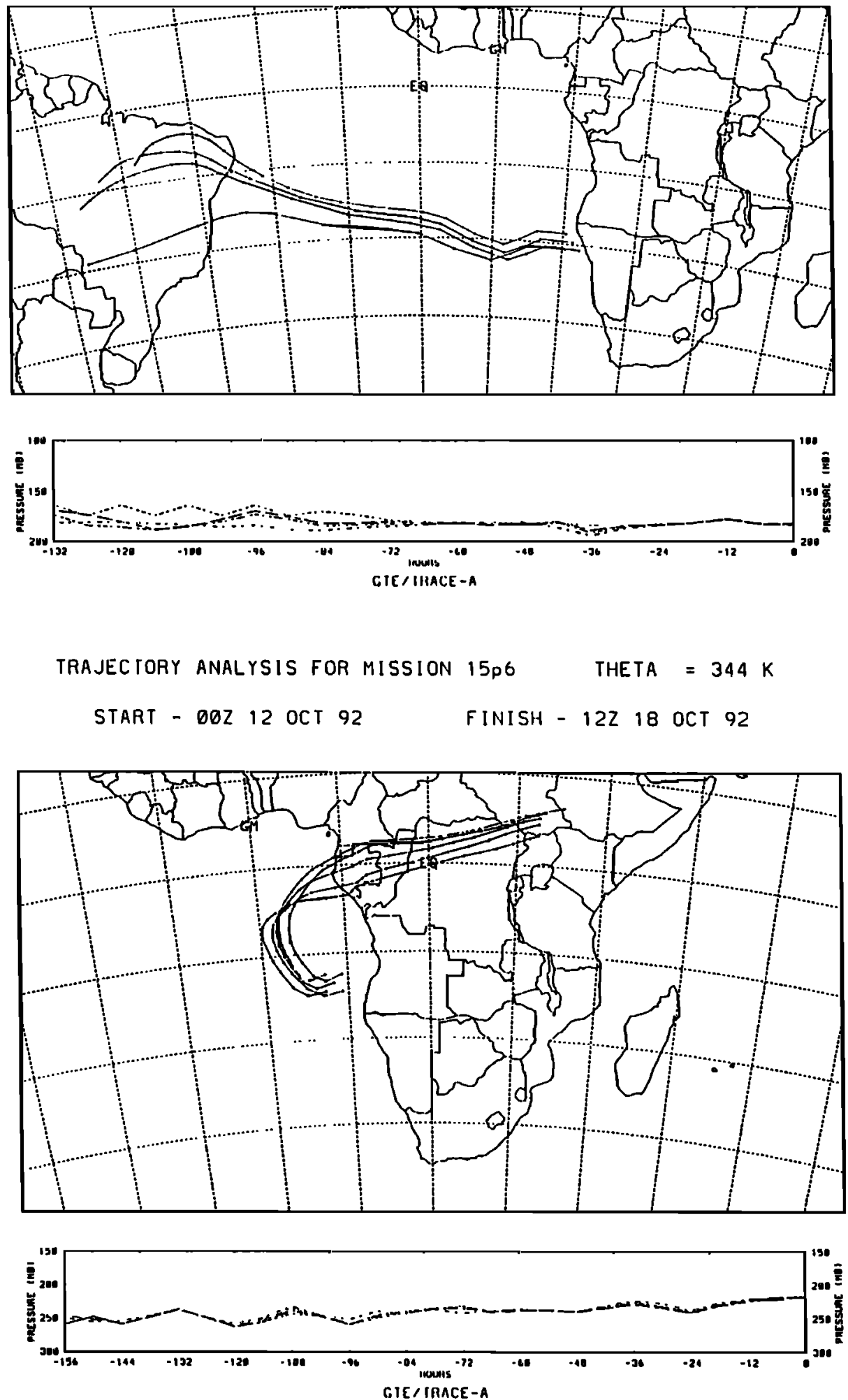

Figure 11. Typical isentropic backward trajectories for air masses sampled at $10-13 \mathrm{~km}$ altitude over the westem basin of the tropical South Atlantic Ocean. Trajectories originating over Brazil indicated that air masses had passed over a mixture of tropical forest, wetland, and savanna ecosystem types. Over Africa the air masses appeared to pass over equatorial tropical forest and wetland regions only. Air masses rarely passed over the savanna regions in southem Africa where satellite observations indicated that biomass fires were concentrated [Fishman et al., this issue]. 
are mixed and diluted in the atmosphere, it is very difficult to deconvolute the various chemical signatures. The aged marine air over the South Atlantic basin exemplifies this problem.

Correlations between various species in high-altitude air parcels were weak $(r \leq 0.5)$ or nonexistent (Figure 10). For example, there appears to be a positive but very general correlation between $\Sigma \mathrm{NO}_{\mathrm{yi}}$ and aerosol number density $(\mathrm{r}=0.41)$. No other species, including $\mathrm{NO}_{x}, \mathrm{HNO}_{3}$ or PAN, showed even a hint of a correlation with aerosol number density. Since aerosol composition was not measured, it is not known if the relationship was driven by nitrate aerosols. Aerosol number densities $>10$ $\mathrm{cm}^{-3}(0.12$ - to $3.1-\mu \mathrm{m}$ diameter $)$ are quite enhanced for the southern hemispheric upper troposphere. Both the TRACE $A$ and ABLE 2A (Atmospheric Boundary Layer Experiment - Amazon Basin dry season) data show that in the absence of pollution plumes free tropospheric aerosol concentrations are $<5 \mathrm{~cm}^{-3}$ [Gregory et al., 1990]. In the boundary layer over Brazil and Africa we observed aerosol concentrations as large as $5 \times 10^{3} \mathrm{~cm}^{-}$ ${ }^{3}$ under conditions of heavy fumigation by biomass fire emissions. Aerosol and $\Sigma \mathrm{NO}_{\mathrm{y} 1}$ concentrations also approached this magnitude near large urban areas in Brazil and Africa.

Methane appeared to show signs of a positive correlation with combustion products ( $\mathrm{CO}$ and PAN plots) and also an anticorrelation with natural biogenic indicators $\left(\mathrm{CO}_{2}\right.$ plot, $\mathrm{CH}_{4}$ emissions, and $\mathrm{CO}_{2}$ uptake). To evaluate the potential for emissions from biomass fires to support the $\mathrm{CH}_{4}$ enhancements at high altitude, we used median values from Table 1 and emission ratios summarized by Crutzen and Andreae [1990]. Comparison of the median mixing ratios of $\mathrm{CH}_{4}$ and $\mathrm{CO}$ at 10 $13 \mathrm{~km}$ altitude (1717 and $87 \mathrm{pbbv}$, respectively) with mean values (1680 and 65 ppbv, respectively) in aged Pacific (mission 8) and South Atlantic marine boundary layer air yields enhancements of 37 and $22 \mathrm{ppbv}$ respectively. This enhancement gives a molar ratio of $1.7 \mathrm{~mol} \mathrm{CH}_{4} / \mathrm{mol} \mathrm{CO}$ compared to a biomass fire emission ratio of about 0.1 [Crutzen and Andreae, 1990]. We conclude from this estimate that significant inputs from sources other than biomass fires are needed to explain the $\mathrm{CH}_{4}$ enhancement at high altitude.

While natural $\mathrm{CH}_{4}$ sources in tropical regions are known to be substantial [Cicerone et al., 1988], they would have to be very large to have affected the entire middle-to-upper troposphere over the tropical South Atlantic basin. Ground-based studies in South America and Africa have not uncovered unusually large natural $\mathrm{CH}_{4}$ emissions from these regions [Bartlett et al., 1988, 1990; Tathy et al., 1992]

Emissions from urban areas, however, can be quite enriched in $\mathrm{CH}_{4}$ [Harriss et al., 1994]. The southeastern coast of Brazil is highly urbanized, and this is a potentially large source region for anthropogenic emissions. There is also a high density $(\geq 12)$ of coal-fired steam-generating plants located in South Africa. The burning of fossil fuels in these plants constitutes a large combustion source, as they represent the third largest anthropogenic sulfur input to the southern hemisphere troposphere [Spiro et al, 1992]. There are also numerous smelter operations located in the Katanga province of northern Zambia (M. O. Andreae, personal communication, 1995).

These anthropogenic sources might explain the substantial enhancement of $\mathrm{C}_{2} \mathrm{H}_{6}$ (and other species) and its poor correlation with $\mathrm{CH}_{3} \mathrm{Cl}$ (Figure 10) at high altitude. We base our argument on comparisons of $\mathrm{C}_{2} \mathrm{H}_{6}$ and $\mathrm{CO}$, two insoluble species with similar atmospheric lifetimes. The ratio $\mathrm{C}_{2} \mathrm{H}_{6} / \mathrm{CO}$ directly over $(\leq 1 \mathrm{~km})$ active savanna fires in Brazil (mission 6) and Zambia (mission 10) had a value of about 6.0 (pptv/ppbv). Based on the median values given in Table 1 ( 590 pptv and $87 \mathrm{ppbv}$ ), the ratio in the upper troposphere over the South Atlantic basin (12.1) was twice that observed in the biomass fire regions. In both cases we subtracted background values of $65 \mathrm{ppbv}$ for $\mathrm{CO}$ and $325 \mathrm{pptv}$ for $\mathrm{C}_{2} \mathrm{H}_{6}$, their mean mixing ratio in aged Pacific and South Atlantic marine boundary layer air. This comparison suggests that sources besides biomass fire emissions contributed to the significant $\mathrm{C}_{2} \mathrm{H}_{6}$ enhancements over the South Atlantic basin.

In the high-altitude air parcels there was little direct evidence for an influence on the chemistry from urban emissions. Generally, $\mathrm{C}_{2} \mathrm{Cl}_{4}$ and $\mathrm{CH}_{3} \mathrm{CCl}_{3}$ are excellent tracers of urban (industrial) emissions [Blake et al., 1995]. Over the South Atlantic basin these species rarely deviated from mixing ratios indicative of aged marine air $\left(\approx 3\right.$ pptv $\mathrm{C}_{2} \mathrm{Cl}_{4}$ and $123 \mathrm{pptv}$ $\mathrm{CH}_{3} \mathrm{CCl}_{3}$ ). Only in air parcels sampled directly downwind of Brazil's urban southeastern coast did we see enhancements in halocarbon species (Figure 3b) [Blake et al., this issue]. Based on these few data, it is hard to tell if Brazilian urban areas are significant sources of halocarbon species. It could be the case that halocarbon species are only slightly enriched in these urban air parcels; mixing processes could then reduce halocarbon mixing ratios to near background values by the time the air parcels are ventilated into upper troposphere. This could explain the poor correlations observed between halocarbon species and combustion products (Figure 10).

It is possible that some of the species enhancements (e.g., $\mathrm{CH}_{4}$ ) in the upper troposphere were related to inputs of northern hemispheric air parcels. During transit flights 4 and 18 we observed a molar ratio of $\approx 21$ for $\mathrm{CH}_{4} / \mathrm{CO}$ in the region $10^{\circ}-20$ ${ }^{\circ} \mathrm{N}$, just north of the ITCZ at $10 \mathrm{~km}$ altitude. Median values in aged marine air at $10-13 \mathrm{~km}$ altitude give a value of 20 for this ratio (Table 1), indicative of northern hemispheric air. However, other comparisons provide evidence against a northern hemispheric $\mathrm{CH}_{4}$ source. The transit flight data (missions 4 and 18) documented an upper tropospheric gradient in $\mathrm{CH}_{4}$ of $\approx 10 \mathrm{ppbv}$ between the northern (1730 ppbv) and the southern hemispheres (1720 ppbv SH), or a north-south difference of $-0.6 \%$. Coincident interhemispheric differences in other long-lived species were significantly greater (e.g., $\mathrm{C}_{2} \mathrm{H}_{6}+10 \%, \mathrm{CH}_{3} \mathrm{CCl}_{3}+12 \%$, CO $+15 \%$, and $\mathrm{C}_{2} \mathrm{Cl}_{4}-70 \%$ ). Thus the relative interhemispheric amounts of various hydrocarbon and halocarbon species are inconsistent with the idea of the northern hemisphere being the principal source of $\mathrm{CO}, \mathrm{CH}_{4}$ or $\mathrm{C}_{2} \mathrm{H}_{6}$ in aged marine air over the South Atlantic basin.

\section{Conclusion}

The positive correlations between $\mathrm{CO}$ and $\mathrm{CH}_{3} \mathrm{Cl}$ and minimal enhancements of $\mathrm{C}_{2} \mathrm{Cl}_{4}$ and various CFCs in air parcels recently advected over the South Atlantic basin strongly suggest an impact on tropospheric chemistry due to continental outflow of biomass burning emissions from Brazil and Africa. The composition of aged marine air also appeared to be affected, as it exhibited an accumulation over the local dry season reflected in enhancements of up to two-fold for $\mathrm{C}_{2} \mathrm{H}_{6}, 30 \%$ for $\mathrm{CO}$, and $10 \%$ for $\mathrm{CH}_{3} \mathrm{Cl}$. Median mixing ratios of $\mathrm{NO}$ and $\mathrm{NO}_{\mathrm{x}}$ were significantly enhanced (up to $\sim 1$ ppbv) above $10 \mathrm{~km}$ altitude and poorly correlated with $\mathrm{CO}$ and $\mathrm{CH}_{3} \mathrm{Cl}$. It appears that in addition to biomass burning, lightning or recycled reactive nitrogen may be an important source of $\mathrm{NO}_{\mathrm{x}}$ in the upper troposphere over the South Atlantic.

Methane exhibited a monotonic increase in altitude from $\sim 1690$ to $1720 \mathrm{ppbv}$ in both aged marine and continental outflow air masses. The largest mixing ratios in the upper troposphere were often anticorrelated with $\mathrm{CO}, \mathrm{CH}_{3} \mathrm{Cl}$, and $\mathrm{CO}_{2}$, suggesting $\mathrm{CH}_{4}$ contributions from natural sources. Based on $\mathrm{CH}_{4} / \mathrm{CO}$ ratios and relationships with various hydrocarbon and CFC species, it appears that inputs from biomass burning and the northern hemisphere cannot explain the distribution of $\mathrm{CO}, \mathrm{CH}_{4}$, or $\mathrm{C}_{2} \mathrm{H}_{6}$ in aged marine air. It would seem necessary to invoke emissions from urban areas to account for their distributions.

An efficient transport mechanism consisting of deep vertical convection over Brazil and Africa coupled with large-scale circulations conveys continental emissions to the upper troposphere over the South Atlantic basin. The resultant geographic 
distribution of long-lived species is remarkably constant at 10 $13 \mathrm{~km}$ altitude. Slow subsidence over the eastern South Atlantic basin undoubtedly plays an important role in maintaining the compositionally similar but more processed air parcels residing from 2 to $10 \mathrm{~km}$ altitude. The common occurrence of values greater than 1 for the ratio $\mathrm{CH}_{3} \mathrm{OOH} / \mathrm{H}_{2} \mathrm{O}_{2}$ in the upper troposphere suggests that precipitation scavenging effectively removed highly water soluble gases $\left(\mathrm{H}_{2} \mathrm{O}_{2}, \mathrm{HNO}_{3}, \mathrm{HCOOH}\right.$, and $\mathrm{CH}_{3} \mathrm{COOH}$ ) and aerosols during vertical convective transport over the continents. However, horizontal injection of biomass burning products over the South Atlantic, particularly water soluble species and aerosol particles, was frequent below $6 \mathrm{~km}$ altitude. These biomass fire products then appear to filter through the extensive stratocumulus cloud deck covering this oceanic region into the marine boundary layer. Here they should be efficiently deposited to the surface ocean, where inputs of atmospheric nitrogen and other nutrient species may have important implications for this oligotrophic marine ecosystem.

Acknowledgments. We appreciate the excellent support provided during the TRACE A expedition by the NASA Ames ground and flight crews of the DC-8 research aircraft. This research was supported by the NASA Global Tropospheric Chemistry program.

\section{References}

Andreae, M. O., et al., Biomass burning and associated haze layers over Amazonia, J. Geophys. Res., 93, 1509-1527, 1988.

Andreae, M. O., A. Chapuis, B. Cros, J. Fontan, G. Helas, C. Justice, Y. J. Kaufman, A. Minga, and D. Nganga, Ozone and Aitken nuclei over equatorial Africa: Airborne observations during DECAFE 88, $J$. Geophys. Res., 97, 6137-6148, 1992.

Bachmeier, S., and H. E. Fuelberg, A meteorological overview of the TRACE A period, J. Geophys. Res., this issue

Bartlett, K. B., P. M. Crill, D. I. Sebacher, R. C. Harriss, J. O. Wilson, and J. M. Melack, Methane flux from the central Amazonian floodplain, J. Geophys Res., 93, 1571-1582, 1988.

Bartlett, K. B., P. M. Crill, J. A Bonassi, J. E. Richey, and R. C. Harriss, Methane flux from the Amazon River floodplain: Emissions during rising water, J. Geophys. Res., 95, 16,773-16,788, 1990.

Bartlett, K. B., G. W. Sachse, J. E. Collins, Jr., and R. C. Harriss, Methane in the tropical South Atlantic: Sources and distribution during the late dry season, $J$. Geophys. Res., this issue.

Blake, D. R., T. -Y. Chen, T. W. Smith Jr., C. J. -L. Wang, O. W. Wingenter, N. J. Blake, F. S. Rowland, and E. W. Mayer, Threedimensional distribution of NMHCs and halocarbons over the northwestern Pacific during the 1991 Pacific Exploratory Mission (PEM-WEST A), J. Geophys. Res., 100, 1763-1778, 1996.

Blake, D. R., N. J. Blake, B. C. Sive, T. -Y. Chen, F. S. Rowland, J. E. Collins Jr., G. W. Sachse, and B. E. Anderson, Biomass burning emissions and vertical distribution of atmospheric methyl halides and gases in the South Atlantic region, J. Geophys. Res, this issue.

Browell, E. V., et al., Ozone and aerosol distributions and air mass characteristics over the South Atlantic basin during the burning season, J. Geophys. Res., this issue.

Cachier, $\mathbf{H}$., and J. Ducret, Influence of biomass burning on equatorial African rains, Nature, 352, 228-230, 1991.

Cachier, H., P. Buat-Menard, M. Fontugne, and R. Chesselet, Source terms and source strengths of the carbonaceous aerosol in the tropics, J. Atmos. Chem., 3, 469-489, 1985.

Cachier, H., M. P. Bremond, and P. Buat-Menard, Carbonaceous aerosols from different tropical biomass burning sources, Nature, 340, 371$373,1989$.

Cahoon, D. C., Jr., B. J. Stocks, J. S. Levine, W. R. Cofer III, and K. P. O'Neill, Seasonal distribution of African savanna fires, Nature, 359 , 812-815, 1992.

Cicerone, R. J., and R. S. Oremland, Biogeochemical aspects of atmospheric methane, Global Biogeochem. Cycles, 2, 299-327, 1988.

Crutzen, P.J., and M. O. Andreae, Biomass burning in the tropics: Impact on atmospheric chemistry and biogeochemical cycles, Science, 250, 1669-16778, 1990.

Crutzen, P. J., L. E. Heidt, J. P. Krasnec, and W. H. Pollock, Biomass burning as a source of atmospheric gases $\mathrm{CO}, \mathrm{H}_{2}, \mathrm{~N}_{2} \mathrm{O}, \mathrm{NO}, \mathrm{CH}_{3} \mathrm{Cl}$ and COS, Nature, 282, 253-256, 1979.

Delmas, R., On the emission of carbon, nitrogen and sulfur in the atmosphere during bushfires in intertropical savannah zones, Geophys. Res. Lett., 9, 761-764, 1982.

Elliott, W. P., and R. K. Reed, A climatological estimate of precipitation for the world ocean, J. Clim. Appl. Meteorol., 23, 434-439, 1984.

Fishman, J., K. Fakhruzzaman, B. Cros, and D. Nganga, Identification of widespread pollution in the southern hemisphere deduced from satellite analyses, Science, 252, 1693-1696, 1991.

Fishman, J., J. M. Hoell Jr., R. D. Bendura, V. W. J. H. Kirchhoff, R. J. McNeal Jr., NASA GTE TRACE A experiment (September October 1992): Overview, J. Geophys. Res, this issue.

Garstang, M., P. D. Tyson, R. Swap, M. Edwards, P Kållberg, and J. A. Lindesay, Horizontal and vertical transport of air over southern Africa, J. Geophys. Res., this issue.

Greenberg, J. P., P. R. Zimmerman, L. Heidt, and W. Pollock, Hydrocarbon and carbon monoxide emissions from biomass buming in Brazil, J. Geophys. Res., 89, 1350-1354, 1984.

Gregory, G. L., E. V. Browell, and L. S. Warren, Amazon Basin ozone and aerosol: Wet season observations, J. Geophys. Res., 95, 16,903$16,912,1990$.

Gregory, G. L., A. S. Bachmeier, D. R. Blake, B. G. Heikes, D. C. Thomton, J. D. Bradshaw, and Y. Kondo, Chemical signatures of aged Pacific marine air: Mixed layer and free troposphere as measured during PEM-WEST A, J. Geophys. Res., I01, 1727-1742, 1996.

Harris, G. W., et al., Airborne observations of strong biogenic $\mathrm{NO}_{\mathrm{x}}$ emissions from the Namibian savanna at the end of the dry season, J. Geophys. Res., this issue.

Harriss, R. C., G. W. Sachse, J. E. Collins Jr., L. Wade, K. B. Bartlett, R. W. Talbot, E. V. Browell, L. A. Barrie, G. F. Hill, and L. G. Burney, Carbon monoxide and methane over Canada: July - August 1990, J. Geophys. Res., 99, 1659-1669, 1994.

Heikes, B. G., Formaldehyde and hydroperoxides at Mauna Loa observatory, J. Geophys. Res., 97, 18,001-18,013, 1992.

Heikes, B. G., et al., Hydrogen peroxide and methylhydroperoxide distributions related to ozone and odd hydrogen over the North Pacific in the fall of 1991, J. Geophys. Res., 101, 1891-1905, 1996.

Heikes, B., M. -H. Lee, D. Jacob, R. Talbot, and J. Bradshaw, Ozonehydroper oxides, oxides of nitrogen, and hydrocarbon budgets in the marine boundary layer over the South Atlantic, J. Geophys Res., this issue.

Helas, G., H. Bingemer, and M. O. Andreae, Organic acids over equatorial africa: Results from DECAFE 88, J Geophys. Res., 97, 6187-6193, 1992

Jacob, D. J., et al., Origin of ozone and $\mathrm{NO}_{r}$ in the Atlantic basin in the tropical troposphere: A photochemical analysis of aircraft observations over the South Atlantic basin, J. Geophys. Res., this issue.

Kirchhoff, V. W. J. H., and R. A. Rasmussen, Time variations of $\mathrm{CO}$ and $\mathrm{O}_{3}$ concentrations in a region subject to biomass burning, $J$. Geophys. Res., 96, 10,899-10,909, 1990.

Kirchhoff, V. W. J. H., and E. V. A. Marinho, Layer enhancements of tropospheric ozone in regions of biomass burning, Atmos. Environ., 28, 69-74, 1994.

Kirchhoff, V. W. J. H., J. R. Alves, F. R. da Silva, and J. Fishman, Observations of ozone concentrations in the Brazilian cerrado during the TRACE A field expedition, J. Geophys. Res, this issue.

Kleinman, L. I., and P. H. Daum, Vertical distribution of aerosol particles, water vapor, and insoluble trace gases in convectively mixed air, J. Geophys. Res., 96, 991-1005, 1991.

Krishnamurti, T. N., H. E. Fuelberg, M. C. Sinha, D. Oosterhof, E. L. Bensman, and V. B. Kumar, The meteorological environment of the tropospheric ozone maximum over the tropical South Atlantic Ocean, J. Geophys. Res., 98, 10,621-10,641, 1993.

Krishnamurti, T. N., M. C. Sinha, M. Kanamitsu, D. Osterhof, H. Fuelburg, R. Chatfield, D. J. Jacob, and J. Logan, Passive tracer transports relevant to the TRACE A experiment, J. Geophys. Res., this issue.

Kuhlbusch, T. A., J. M. Lobert, P. J. Crutzen, and P. Warneck, Molecular nitrogen emissions from denitrification during biomass burning, Nature, 351, 135-137, 1991.

Lacaux, J. P., R. Delmas, G. Kouadio, B. Cros, and M. O. Andreae, Precipitation chemistry in the Mayombe Forest of equatorial Africa, J. Geophys. Res., 97, 6195-6206, 1992. 
Leslie, A. C D., Aerosol emissions from forest and grassland burning in the southern Amazon Basin and central Brazil, Nucl. Instrum. and Method ,181, 345-351, 1981.

Levine, J. S., et al., Biogenic soil emissions of nitric oxide (NO) and nitrous oxide $\left(\mathrm{N}_{2} \mathrm{O}\right)$ from savanna in South Africa: The impact of wetting and burning, $J$. Geophys. Res., this issue.

Lobert, J. M., D. H. Scharffe, W. -M. Hao, T. A. Kuhlbusch, R. Seuwen, P. Warneck, and P. J. Crutzen, Experimental evaluation of biomass burning emissions: Nitrogen and carbon containing compounds, in Global Biomass Burning - Atmospheric, Climatic, and Biospheric Implications, edited by J. S. Levine, pp. 289-304, The MIT press, Cambridge, Mass., 1991.

McKeen, S. A., and S. C. Liu, Hydrocarbon ratios and photochemical history of air masses, Geophys. Res. Lett., 20, 2363-2366, 1993.

Moody, J. L., A. A. P. Pszenny, A. Gaudry, W. C. Keene, J. N. Galloway, and G. Polian, Precipitation composition and its variability in the southern Indian Ocean: Amsterdam Island, 1980-1987, $J$. Geophys. Res., 96, 20,769-20,786, 1991.

Newell, R. E., S. T. Shipley, V. S. Connors, and H. G. Reichle Jr., Regional studies of potential carbon monoxide sources based on space shuttle and aircraft measurements, J. Atmos. Chem., 6, 61-81, 1988.

Olson, J. R., J. Fishman, V. W. J. H. Kirchhoff, D. Nganga, and B. Cros, An analysis of the distribution of $\mathrm{O}_{3}$ over the southern Atlantic region, J. Geophys. Res., this issue.

Paerl, H. W., Enhancement of marine primary production by nitrogenenriched acid rain, Nature, 315, 747-749, 1985.

Paerl, H. W., Emerging role of atmospheric nitrogen deposition in coastal eutrophication: Biogeochemical and trophic perspectives, Can. J. Aquat. Sci., 50, 2254-2269, 1993.

Pickering, K. E., A. M. Thompson, J. R. Scala, W. Tao, and J. Simpson, Ozone production potential following convective redistribution of biomass burning emissions, J. Atmos. Chem., 14, 297-313, 1992.

Pickering, K. E., A. M. Thompson, D. P. McNamara, and M. R. Schoeberl, An intercomparison of isentropic trajectories over the South Atlantic, Mon. Weather Res., I22, 864-879, 1994.

Pickering, K. E., et al., Convective transport of biomass burning emissions over Brazil during TRACE A, J. Geophys Res, this issue.

Rudolph, J, A. Khedim, and B Bonsang, Light hydrocarbons in the tropospheric boundary layer over tropical Africa, J. Geophys. Res., 97, 6181-6186, 1992.
Singh, H. B., and P. B. Zimmerman, Atmospheric distribution and sources of nonmethane hydrocarbons, in Gaseous Pollutants: Characterization and cycling, edited by J. O. Nriagu, pp. 177-235, John Wiley, New York, 1992.

Smyth, S., et al., Factors influencing the upper free tropospheric distribution of reactive nitrogen over the South Atlantic during the TRACE A experiment, $J$. Geophys Res., this issue.

Spiro, P. A., D. J. Jacob, and J. A. Logan, Global inventory of sulfur emissions with $1^{\circ} \times 1^{\circ}$ resolution, J. Geophys. Res., 97, 6023-6036, 1992.

Steele, L. P., E. J. Dlugokencky, P. M. Lang, P. P. Tans, R. C. Martin, and K. A. Masarie, Slowing down of the global accumulation of atmospheric methane during the 1980s, Nature, 358, 313-316, 1992.

Tathy, J. P., B. Cros, R. A. Delmas, A. Marenco, J. Servant, and M. Labat, Methane emission from flooded forest in central Africa, $J$. Geophys. Res., 97, 6159-6168, 1992.

Thompson, A. M., K. E. Pickering, D. P. McNamara, R. D. Peters, Effect of marine stratocumulus on TOMS ozone, J. Geophys. Res., 98, 23,051-23,057, 1993.

B. E. Anderson, G. L. Gregory, and G. W. Sachse, NASA Langley Research Center, Hampton, VA 23681.

D. R. Blake and N. R. Blake, Department of Chemistry, University of California - Irvine, Irvine, CA 92717.

J. D. Bradshaw, S. T. Sandholm, and S. Smyth, School of Earth and Atmospheric Sciences, Georgia Institute of Technology, Atlanta, GA 30332.

J. E. Collins and A. S. Bachmeier, Lockheed Engineering and Sciences Company, Hampton, VA 23681.

B. G. Heikes, Center for Atmospheric Chemistry Studies, University of Rhode Island, Narragansett, TI 02882.

B. L. Lefer and R. W. Talbot (corresponding author), Institute for the Study of Earth Oceans, and Space, University of New Hampshire, Morse Hall, Durham, NH 03824. (e-mail: rwt@christa.unh.edu)

H. B. Singh, NASA Ames Research Center, Moffett Field, CA 94035.

(Received March 14, 1995; revised November 15, 1995; accepted November 15, 1995.) 